Ks. Antoni SWOBODA

(Poznań, UAM)

\title{
WYCHOWANIE POTOMSTWA NA PRZYKLADZIE KOBIERCÓW KLEMENSA ALEKSANDRYJSKIEGO I LISTÓW ŚW. HIERONIMA ZE STRYDONU
}

Pytania, które sobie dzisiaj stawia człowiek, często dotyczą wychowywania młodego pokolenia: jakie wartości przekazać, oraz co powinno stanowić fundament wychowania. Wraz tymi pytaniami rodzą się kolejne - kto powinien być w pierwszym rzędzie wychowawcą i jakie powinien on spełniać kryteria, aby jego misja przyniosła oczekiwane owoce. Nauczanie Kościoła nie unika tych tematów, ale z naciskiem podkreśla, że obowiązkiem małżonków i najważniejszą częścią ich apostolstwa jest między innymi „mocno podkreślać prawo i obowiązek rodziców i opiekunów do chrześcijańskiego wychowania dzieci [...], a rządzący społeczeństwem winni brać po uwagę potrzebę wychowania dzieci"'. Tenże Sobór z ubolewaniem zauważa, że wielka liczba dzieci i młodzieży pozbawiona jest nie tylko podstawowego wykształcenia, a ,wielu innych należytego wychowania, w którym kultywuje się zarazem prawdę i miłość" ${ }^{2}$. Tymczasem, jak czytamy w tym samym dokumencie soborowym, dzieci i młodzież mają prawo, by pobudzano ich do oceny wartości moralnych wedle prawidłowego sumienia i przyjmowania owych wartości przez osobisty wybór, a również do doskonalszego poznawania i miłowania Boga"’3.

Wychowanie moralne, jak podkreśla Guido Gatti, rozumiane jako pedagogia wolności, stanowi pierwszorzędny cel każdego wychowania i każdego samowychowania moralnego. Wychowywać i wychowywać się do poprawności moralnej, to przede wszystkim kształtować się do wolności z niewoli grzechu, tak na płaszczyźnie osobowej, jak i społecznej. Wychowanie moralne jest więc wychowywaniem do wolności. Chrześcijańskie wychowanie moralne, znalazło swoje proprium w pedagogice wolności, rozumianej jako wcielenie wiary, która umożliwia żyć jako dziecko Boże w „żywiołowości” miłości.

\footnotetext{
${ }^{1}$ Concilium Vaticanum II: Apostolicam actuositatem 11. Przekład polski w: Sobór Watykański II. Konstytucje - dekrety - deklaracje: Dekret o apostolstwie świeckich 11, Poznań 2002, 387.

${ }^{2}$ Concilium Vaticanum II: Gravissimum educationis momentum. Introductio. Przekład polski w: tamże: Deklaracja o wychowaniu chrześcijańskim. Wstęp, s. 315.

${ }^{3}$ Por. tamże 1, s. 316.

${ }^{4}$ Por. G. Gatti, Educazione morale come pedagogia della libertà, w: Dizionario teologico interdisciplinare, Torino 1977, 407.
} 
Zagadnieniem wychowania potomstwa interesowano się już w czasach starożytnych tak w środowisku greckim, jak i rzymskim okresu przedchrześcijańskiego oraz chrześcijańskiego. Na ten temat posiadamy już obszerną literaturę zarówno tak o charakterze encyklopedycznym ${ }^{5}$, jak i opracowań monograficznych, a także prac, które pośrednio podejmują ten temat ${ }^{6}$.

Prezentowane opracowanie ma na celu przybliżenie tematyki wychowania na przykładzie Kobierców Klemensa Aleksandryjskiego $(† 212)^{7}$ i Listów św. Hieronima (347-419) ${ }^{8}$. Gdy chodzi o Listy Hieronima to, jak zauważa A. Stęp-

\footnotetext{
${ }^{5}$ Por. np. P. Blomenkamp, Erziehung, RACh VI 504-559.

${ }^{6}$ Por. np. niektóre publikacje w języku polskim: M. Brożek, Kształcenie $i$ wychowanie w najdawniejszej starożytności rzymskiej, „Meander” 24 (1969) 313-325; J. Błaszczyk - A. Ossowska - W. Rączewska, Historia wychowania rodzinnego i ksztatcenie w starożytności. Przewodnik bibliograficzny, Bydgoszcz 1997; F. Drączkowski, Koncepcja wychowania chrześcijańskiego w ujęciu Klemensa Aleksandryjskiego i Jana Chryzostoma, VoxP 29 (2009) t. 53-54, 313-328; A. Eckmann, Biblijne podstawy Chryzostomowego programu wychowania dzieci, VoxP 29 (2009) t. 53-54, 329336; J. Jundził1, Poczatki wychowania. Wychowanie w świecie starożytnym w: Historia wychowania, red. J. Hellwig, Poznań 1994, 9-18; tenże, Teoretyczne problemy wychowania w rodzinie rzymskiej (III w. prz. Chr. - III w. po Chr.), Bydgoszcz 1987; tenże Praktyka i teoria wychowania w rodzinie w pismach Seneki, Epikteta i Marka Aureliusza, VoxP 5 (1985) z. 8-9, 51-61; O. Jurewicz - L. Winniczuk, Starożytni Grecy i Rzymianie w życiu prywatnym i państwowym, Warszawa 1973; K. Korus, Program wychowawczy Plutarcha z Cheronei, Kraków 1978; tenże, Ksztatcenie $i$ wychowanie domowe w Rzymie w I i 1. pot. II wieku, „Filomata” 1977, nr 304, 206-215; tenże, Grecka teoria pedagogiczna a problem porzucania dzieci „Meander” 9 (1979) 439-454; S. Kot, Historia wychowania. Od starożytnej Grecji do połowy XVIII wieku, Warszawa 1996; G. Kuleczka, Dzieci w systemie prawnym starożytnego Rzymu, „Meander” 34 (1979) 237-250; J. Kułaczkowski, Rodzina jako środowisko wychowawcze w starożytnej Grecji i Rzymie, SG 12 (1998) 178-187; S. Longosz, Śpiew i muzyka w rodzinie środkiem wychowania w pedagogii Jana Chryzostoma , „Roczniki Nauk o Rodzinie" 1 (2009) 13-55; tenże, Rodzina wczesnochrześcijańska Kościołem domowym, RT 51 (2004) z. 10, 27-56; Ł. Kurdybacha, Ideat wychowawczy w rozwoju dziejowym, Warszawa 1948; H.I. Marrou, Historia wychowania w starożytności, tłum. S. Łoś, Warszawa 1969; E. Osek, Chryzostomowa terminologia wychowania, VoxP 29 (2009) t. 53-54, 337-393; W. Rączewska, Narodziny i wczesna opieka nad dzieckiem w rodzinie rzymskiej, „Studia Pedagogiczne” 18 (1992) 59-68; W. Rudnicka, Dziecko w szkole elementarnej za czasów cesarstwa rzymskiego, w: Dziecko w rodzinie i społeczeństwie. Starożytność - średniowiecze, red. J. Jundziłł - D. Żołądź-Strzelczyk, Bydgoszcz 2002, 143154; A. Stępniewska, Wychowanie rodzinne dziewczat w pedagogice św. Hieronima, VoxP 5 (1985) z. 8-9, 151-176; A. Uciecha, Religijny program wychowania w ujęciu Jana Chryzostoma, VoxP 29 (2009) t. 53-54, 421-432; S. Wasilewski, Metody wychowawcze św. Jana Chryzostoma, VoxP 29 (2009) t. 53-54, 433-446; L. Winniczuk, Ludzie, zwyczaje i obyczaje starożytnej Grecji i Rzymu, Warszawa 1983; A. Zmorzanka, Wychowanie dziewczat w nauczaniu Jana Chryzostoma, VoxP 29 (2009) t. 53-54, 459-480.

${ }^{7}$ Por. Clemens Alexandrinus, Stromata, ed. O. Stählin - L. Frühtel, GCS 52 (I-VI), Berlin 1960 i GCS 17 (VII-VIII), Berlin 1970, thum. J. Niemirska-Pliszczyńska: Klemens Aleksandryjski, Kobierce zapisków filozoficznych dotyczacych prawdziwej wiedzy, I-II, Warszawa 1994.

${ }^{8}$ Por. Hieronymus, Epistolae, ed. PL 22, 325-1224; lub ed. I. Hilberg, CSEL 54-56 (Wien 19101918), tłum. J. Czuj: Św. Hieronim, Listy, I-III, Warszawa 1952-1954, poprawiony przedruk (wraz z tekstem łacińskim) w opracowaniu M. Ożóg - H. Pietras, t. 1-5, ŹMT 54, 55, 61,63 i 68, Kraków 2010-2013.
} 
niewska, jego pedagogiczne poglądy, dotyczące początkowego wychowania chrześcijańskich dziewcząt z przełomu IV i V wieku, obecne między innymi w jego korespondencji, nie są systematycznie opracowaną teorią lub nauką o wychowaniu czy kształceniu dzieci, ale zbiorem uwag, które w szerszym sensie można nazwać wczesnochrześcijańską pedagogikąa. Strydończyk wypowiadając się na temat wychowania starał się nie tylko dostosować do potrzeb chrześcijańskiego wychowania podręcznik Kwintyliana przejmując z niego tylko to, co uznał za niezbędne dla chrześcijańskiego dziecka, ale także powoływał się na innych autorów, jak Arystoteles czy Cyceron, nie pomijając przy tym nauki z Pisma Świętego. Z kolei wcześniejszy Klemens Aleksandryjski w swych Kobiercach, interesuje się przede wszystkim stosunkiem religii chrześcijańskiej do wiedzy ludzkiej, zwłaszcza relacją między wiarą chrześcijańską a filozofią grecką. Obok tych zagadnień, odwołując się także do autorów niechrześcijańskich, porusza również tematy związane z rodziną i wychowaniem.

Podejmując się opracowania tak sformułowanego tematu pragniemy przy pomocy metody analitycznej, badającej wypowiedzi obu autorów, doprowadzić do pewnej syntezy, ukazującej ich poglądy na temat wychowania młodego człowieka, które dokonywało się w środowisku aleksandryjskim w III wieku oraz w rzymskim na przełomie IV i V wieku. Niniejszy artykuł składać się będzie z czterech zasadniczych części: w pierwszej przybliżymy stanowisko obu autorów odnoszące się do założeń ogólnych wychowania człowieka; w drugiej poszukamy odpowiedzi na pytanie, kto jest odpowiedzialny za wychowanie człowieka; trzecia część poświęcona zostanie zagadnieniu człowieka rozumianego jako podmiot procesu wychowawczego; w ostatniej wreszcie przybliżone zostanie nauczanie Klemensa i Hieronima na temat przedmiotu formacji, na którą składa się: religijna, moralna i intelektualna. Całość opracowania zakończona zostanie stosownymi wnioskami z przeprowadzonej analizy obu tekstów.

\section{WYCHOWANIE CZŁOWIEKA - ZAŁOŻENIA OGÓLNE}

Wychowanie, jak można wywnioskować z lektury listów św. Hieronima, ma uchronić dziecko przede wszystkim przed złem ${ }^{10}$. Jest to pierwszy i to negatywny aspekt, obecny w procesie wychowawczym, który jednak, jak zauważa nasz Autor, nie może się jednak ograniczać tylko i wyłącznie do tego wymiaru. Istnieje bowiem i drugi wymiar, mający swój aspekt pozytywny, który polega na nauczeniu dziecka umiejętności przezwyciężania zła dobrem. Strydończyk przekazując tę refleksję dokonał jej na tle pewnego rodzaju porównania pomiędzy filozofami świeckimi (philosophi saeculi), którzy zazwyczaj, jak czytamy, ,starą miłość usuwają przez nowe uczucie” zgodnie

\footnotetext{
${ }^{9}$ Por. Stępniewska, Wychowanie rodzinne dziewczat, s. 172.

${ }^{10}$ Por. Hieronymus, Epistola 107, 6, PL 22, 873.
} 
ze znaną zasadą „klin klinem" ${ }^{11}$. To jednak powoduje, zdaniem Hieronima, że „występek leczony jest przez występek”, a ,grzech grzechem”. Dlatego w przekonaniu Autora i w odróżnieniu od tych praktyk, chrześcijanie pokonują zło przez miłość do zdobywania cnót, akcentując w ten sposób konieczność obecności pozytywnego czynnika w kształtowaniu osobowości człowieka ${ }^{12}$. Już w świetle tego można powiedzieć, że Hieronim określając cele wychowawcze, nie tylko odwołuje się do autorów niechrześcijańskich, jak na przykład do retora Kwintyliana (35-95) i Cycerona, ale ich przemyślenia stara się ubogacić treściami chrześcijańskimi ${ }^{13}$, dostosowując je do aktualnie poruszanego zagadnienia, związanego z tematyką wychowania.

W podobny sposób podchodził do tego zagadnienia w środowisku aleksandryjskim III wieku Klemens. Zauważa on jednak różne strony, iż na przykład dla stoików wychowanie potomstwa jest rzeczą obojętną dla dobra moralne$\mathrm{go}^{14}, \mathrm{z}$ drugiej zaś jest świadom, że dla innych podjęcie się procesu wychowawczego wobec dziecka może być nie akceptowanym ciężarem. Potwierdzenie tego znajdujemy w uwadze wypowiedzianej w kontekście jego nauczania o zasadności wyboru życia w małżeństwie. Autor ten stara się przekonać, że „nie wolno zapatrywać się negatywnie na rozsądne małżeństwa, o ile wychowanie dzieci nie stanowi dla kogoś zbyt wielkiej przykrości”"15. Innymi słowy, według tego Autora wychowywanie może dla niektórych osób być czymś przykrym ze względu na to, że na przykład „odciaga go od służby Bożej”16. Tak więc, według Klemensa, dla osób, które wybrały wspólną drogę życia w małżeństwie, wychowanie jest obowiązkiem spełnianym wobec drugiego człowieka $^{17}$, co również przypomina Hieronim swym adresatkom listów: Salwinie $^{18}$ i Lecie $^{19}$.

Dla Hieronima oznacza to także, zwłaszcza w sytuacji, gdy trudem wychowania zajmuje się kobieta po śmierci własnego męża, że jej dzieci w pewnym sensie „zastępują nieobecnego małżonka"20, co potwierdza także Klemens, gdy mówi, że dzieci są żywą pamięcią o mężu, który już nie żyje, a one noszą jego imię̨21. Kontynuując swą refleksję Strydończyk uważa, że Salwina, w za-

${ }^{11}$ Por. Hieronymus, Epistola 125, 14, PL 22, 1080: „solent amorem veterem amore novo, quasi clavum clavo expellere", ŹMT 63, 160; zob. Cicero, Tusculanae disputationes IV 75.

${ }^{12}$ Por. Hieronymus, Epistola 125, 14, PL 22, 1080: „Illi vitium vitio, peccatumque peccato medicantur, nos amore virtutum, vitia superemus"; zob. Stępniewska, Wychowanie rodzinne dziewczat, s. 155.

${ }^{13}$ Por. Stępniewska, Wychowanie rodzinne dziewczat, s. 157.

${ }^{14}$ Por. Clemens Alexandrinus, Stromata II 23, 138, 5.

${ }^{15}$ Clemens Alexandrinus, Stromata III 9, 67, 1, GCS 52, 226, Niemirska-Pliszczyńska I 267.

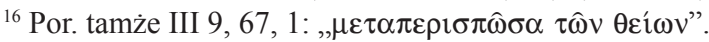

${ }^{17}$ Por. tamże II 23, 140, 1; zob. A. Oepke, Ehe, RACh IV 662.

${ }^{18}$ Por. Hieronymus, Epistola 79, 7, PL 22, 728-730.

${ }^{19}$ Por. Hieronymus, Epistola 107, 3, PL 22, 870.

${ }^{20}$ Por. Hieronymus, Epistola 79, 7, PL 22, 728-730.

${ }^{21}$ Por. Clemens Alexandrinus, Stromata II 23, 141, 3, GCS 52, 191. 
mian za jednego człowieka, otrzymała dwoje dzieci, przez co powiększyła się liczba osób ukochanych. Z tego też tytułu zaleca, by swym dzieciom oddała to, co winna dać małżonkowi, a jej miłość żywiona wobec obecnych, winna ukoić tęsknotę za nieobecnym ${ }^{22}$.

Aby zaś proces wychowawczy mógł przebiegać w prawidłowy sposób, jak to wynika z nauczania obu autorów, należy w tym celu wytworzyć odpowiedni klimat, aby dziecko nie tylko mogło rozwijać się prawidłowo, tak od strony psychicznej jak osobowościowej, ale także by zżyło się ze swoją rodzinąa ${ }^{23}$.

Wychowanie, zwłaszcza młodego człowieka, musi być, jak wskazuje na to kontekst wypowiedzi Hieronima, odpowiedzialne ${ }^{24}$. Innymi słowy, należy tak postępować, aby dziecko, tu Strydończyk ma na uwadze dziewczynkę, nie uczyło się od młodości posiadania czegoś, czego później będzie się musiało po$z_{\text {zbyć }}^{25}$. Kolejną ważną wskazówką, udzieloną przez tegoż Autora, jest przypomnienie, aby dzieci były zawsze traktowane sprawiedliwie: nie tylko nie należy ich opuszczać w potrzebie, ale winno się je kochać „w równości” $(2 \text { Kor } 8,13)^{26}$.

W wychowaniu dziecka obaj nasi Autorzy w swych wskazaniach nie pomijali konieczności stosowania wobec niego nagany. Potwierdzenie tego znajdujemy na przykład u Klemensa, który opierając się na Księdze Przysłów (10, $17 ; 29,15)$ zauważa, że wychowanie, w którym nie ma miejsca na słuszną nagane ,prowadzi na manowce”. Stąd też w jego przekonaniu „,chłosta i napomnienia dają wychowanie w mądrości”. Stosując jednak te metody przypomina, że napomnienia te winny być zawsze wypowiadane w duchu miłości ${ }^{27}$. Ta refleksja, ubogacona tym razem aluzją do platońskiego Protagorasa, została uzupełniona o kolejną uwagę, w której nasz Autor podkreśla, że podobnie jak dzieci są karane przez nauczyciela lub ojca, tak wszyscy ludzie przez Opatrzność Bożą. Bóg jednak, jak zauważa Aleksandryjczyk, „nie mści się - bo zemsta jest odpłatą za zło - ale karze ku pożytkowi karanych, zarówno ich wspólnemu jak i indywidualnemu"28. Stąd też Aleksandryjczyk, czyniąc aluzję do nauczania św. Pawła (Kol 3, 21), zwraca się do ojców, by swym postępowaniem nie rozdrażniali swych dzieci, aby te nie upadały na duchu ${ }^{29}$.

To spostrzeżenie zdaje się podzielać także i Hieronim. Mówiąc bowiem o obowiązkach biskupa i ojca w rodzinie, odwołując się pośrednio do słynne-

${ }^{22}$ Por. Hieronymus, Epistola 79, 7, PL 22, 728-730; zob. Stępniewska, Wychowanie rodzinne dziewczat, s. 154.

${ }^{23}$ Por. Stępniewska, Wychowanie rodzinne dziewczat, s. 153.

${ }^{24}$ Por. Hieronymus, Epistola 107, 4, PL 22, 871-872.

${ }^{25}$ Por. Hieronymus, Epistola 128, 2, PL 22, 1098: „revera bono consilio, ne habere discat in tenero, quod postea ponere compellatur".

${ }^{26}$ Por. Hieronymus, Epistola 120, 1, PL 22, 984: „sed ex aequalitate eos amet”, ŹMT 63, 56.

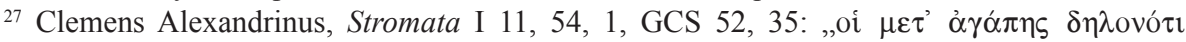

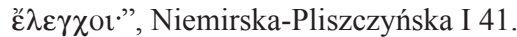

${ }^{28}$ Tamże VII 16, 102, 5, GCS 17, 72, Niemirska-Pliszczyńska II 302; zob. Plato, Protagoras 324BC.

${ }^{29}$ Por. Clemens Alexandrinus, Stromata IV 8, 65, 2. 
go mówcy, filozofa i prawnika - Cycerona, podkreśla, że tak ojciec jak i biskup winni wzbudzać miłość, a nie lęk i dodaje za starożytnym przysłowiem, że „człowiek nienawidzi tego, kogo się boi, i pragnie zguby tego, kogo nienawidzi" ${ }^{30}$. Nie poprzestając jednak na tym stwierdzeniu czyni aluzję do pierwszego listu św. Jana $(1 \mathrm{~J} 4,18)$ i uczy, że ,pierwsze początki polegają na bojaźni, ale «miłość doskonała usuwa bojaźń»" 31 .

Stosowanie jednak nagany wobec dziecka nie może być przesadne, gdyż wywołać może zupełnie odwrotny skutek, niż się zamierzało. Dlatego też Hieronim w postawionym przez siebie pytaniu podkreśla, że „,dobrzy rodzice winni starać się nie pobudzać do gniewu swych synów i zbytkiem surowości nie doprowadzać do srogości nawet bardzo łagodnych"32. Tę wypowiedź uzupełnia w pewien sposób kolejna, w której w sposób obrazowy, powołując się pośrednio na wspomnianego Cycerona oraz Kwintyliana, adresatowi listu Rustykusowi przypomina, że jego matka stosowała wobec niego w przeszłości „wędzidła, a nie ostrogi”"33. Natomiast wobec córki, Strydończyk proponuje inną zasadę postępowania: uważa, że nie powinno się jej „karcić w przypadku opieszałości”, ale pochwałami i podarkami „podtrzymywać zdolności, żeby zarówno cieszyła się z sukcesów, jak i cierpiała z powodu niepowodzeń" ${ }^{34}$. W dalszej części tego samego listu, w porównaniu z Klemensem, jedynie Hieronim wspomina pośrednio o dobrych skutkach rywalizacji w nauce, wśród wychowywanych dziewcząt. Ta myśl, w naszym przekonaniu, zawarta jest w stwierdzeniu Autora, z którego wynika, że dziewczynka winna mieć koleżanki, którym by zazdrościła, i których sława niepokoiłaby ją ${ }^{35}$.

\section{OSOBY ODPOWIEDZIALNE ZA WYCHOWANIE DZIECKA}

Przybliżone w poprzednim rozdziale ogólne założenia, odnoszące się do wychowania potomstwa, nasuwają pytanie o to, kto powinien zajmować się wychowaniem dzieci? Odpowiadając na tak postawione pytanie, należy przede wszystkim odwołać się do wypowiedzi Klemensa, który w analizowanym przez nas dziele, powołując się na Ewangelię według św. Mateusza $(18,20)$ zauważa, że mężczyzna łączy się z kobietą za sprawą Boga i stąd razem z dziec-

${ }^{30}$ Hieronymus, Epistola 82, 3, PL 22, 737: „Amare enim parens debet. Amari parens et Episcopus debet, non timeri”, ŹMT 61, 16; por. Cicero, De officiis II 23.

${ }^{31}$ Por. Hieronymus, Epistola 82, 3, PL 22, 737, ŹMT 61, 16-17.

${ }^{32}$ Tamże 82, 3, PL 22, 738: „quanto magis bonis parentibus providendum est, ne ad iracundiam provocent filios suos, et nimietate duritiae, etiam lenissimos, asperos esse compellant?", ŹMT 61, 17".

${ }^{33}$ Por. Hieronymus, Epistola 125, 6, PL 22, 1075: „nec calcaribus in te, sed fraenis uterentur”, ŹMT 63, 155; zob. Cicero, De oratore III 36; Quintilianus, Institutio oratoria II 8, 11.

${ }^{34}$ Hieronymus, Epistola 107, 4, PL 22, 871: „Non est obiurganda, si tardior sit, sed laudibus excitandum ingenium, ut et vicisse gaudeat, et victa doleat", ŹMT 61, 152; por. Epistola 128, 1, PL 22, 1096; zob. Stępniewska, Wychowanie rodzinne dziewczat, s. 156.

${ }^{35}$ Por. Hieronymus, Epistola 107, 6, PL 22, 871: „Habeat et in discendo socias, quibus invideat: quarum laudibus mordeatur", ŹMT 61, 151. 
kiem stanowią oni wspólnotę, w której mieszka Bóg ${ }^{36}$. Innymi słowy, Aleksandryjczyk w swym nauczaniu na temat rodziny, w której dokonuje się proces wychowawczy dziecka, pochwala przede wszystkim środowisko ludzi głęboko wierzących, wskazując tym samym na konieczność wytworzenia właściwego klimatu, sprzyjającemu wychowaniu. Jak bowiem czytamy z kolei u Hieronima, „Święty i wierny dom uświęca jednego niewiernego" ${ }^{37}$. Te słowa, wypowiedziane przez Klemensa i Hieronima, w sposób jednoznaczny uwypuklają prawdę, że rodzina winna być właściwym środowiskiem sprzyjającym wychowaniu potomstwa. Na podstawie analizy pism naszych Autorów przekonujemy się, że pierwszymi wychowawcami dziecka są przede wszystkim rodzice, którzy muszą pod tym względem spełniać określone wymagania, właściwe dla matki i ojca. Lektura dzieł, będących przedmiotem naszego zainteresowania, pozwala wpierw na stwierdzenie, iż ilościowo więcej wypowiedzi na ten temat znajdujemy w Listach Hieronima, aniżeli Kobiercach Klemensa.

Tak więc Hieronim, pisząc na temat wymagań stawianych matce jako wychowawczyni dziecka, pochwala na przykład Paulę za to, że jest ona kobieta do głębi pobożną ${ }^{38}$, co dało się również zauważyć po śmierci jej męża, kiedy to jeszcze silniej związała się z Bogiem ${ }^{39}$. Te same słowa wypowiedział także pod adresem matki adresatki listu do Furii, Tycjany, gdy z uznaniem pisał o jej głębokiej wierze, podejmowanych umartwieniach, udzielanej jałmużnie ubogim, poszanowaniu osób duchownych, pokorze w sercu i odzieniu oraz umiarkowaniu w mowie ${ }^{40}$. Te pochwały odnosiły się także do matki Rustyka, którą Autor oceniał jako religijną i świętą ${ }^{41}$.

Wszystkie te spostrzeżenia Hieronima zgodne są z tym, co także stanowiło przedmiot zainteresowania Klemensa. Mówiąc bowiem na temat obowiązków żony Aleksandryjczyk jest zdania, że winna ona być swemu małżonkowi pomocna także w zakresie wiary w Jezusa Chrystusa ${ }^{42}$. Niewątpliwie, Hieronim kierując się ówczesnym podziałem ról, jakie spełniali w ramach rodziny ojciec i matka wobec córek i synów, przypomina, że matka dla córki winna być nauczycielką, którą ma ona naśladować ${ }^{43}$, a nie odwrotnie ${ }^{44}$, być podobna do tej, o której czytamy w innym miejscu, że wychowywała, pielęgnowała i nauczała

\footnotetext{
${ }^{36}$ Por. Clemens Alexandrinus, Stromata III 68, 1; zob. G. Delling, Eheleben, RACh IV 703.

${ }^{37}$ Hieronymus, Epistola 107, 1, PL 22, 868: „Sancta et fidelis domus unum sanctificat infidelem”, ŹMT 61, 149.

${ }^{38}$ Por. Hieronymus, Epistola 108, 4, PL 22, 880.

${ }^{39}$ Por. tamże 108, 5, PL 22, 880-881.

${ }^{40}$ Por. Hieronymus, Epistola 54, 6, PL 22, 552.

${ }^{41}$ Por. Hieronymus, Epistola 125, 6, PL 22, 1075.

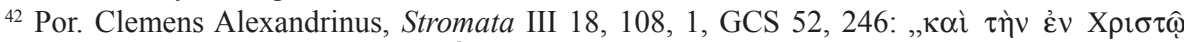

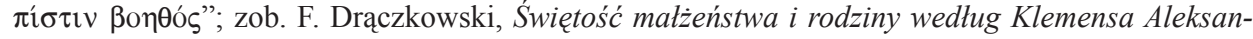
dryjskiego, VoxP 5 (1985) z. 8-9, 123.

${ }^{43}$ Por. Hieronymus, Epistola 107, 9, PL 22, 875.

${ }^{44}$ Por. Hieronymus, Epistola 117, 11, PL 22, 959.
} 
dziewice ${ }^{45}$. Z tego też względu konieczna jest stała obecność matki przy dziec$\mathrm{ku}$, a gdy jest to córka, to jedynie w towarzystwie matki może ona pojawiać się w miejscach publicznych, także i w kościele, obie powinny też spędzać czas podczas obchodzonych wigilii i nocnych czuwann ${ }^{46}$. Również w sytuacji gdy matka udaje się w podróż, nie powinna zostawiać córki samej w domu, gdyż ta „winna umieć żyć w obecności matki”. Pozostawianie zaś jej samej w domu powinno córkę napełniać lękiem ${ }^{47}$.

Okazuje się, że Hieronim, choć chyba najwięcej w swych listach pisał na temat wychowania córki przez matkę, to jednak nie pominął też faktu, że matka może także wychowywać własnego syna. Dla Strydończyka takim przykładem była Kornelia, matka Grakchów (II w. prz. Chr.), która, jak zauważa, w znaczny sposób przyczyniła się do ich wymowy ${ }^{48}$ a także matka Rustyka, która wysłała go do Rzymu po odbytych studiach w Galii ${ }^{49}$.

To, że matka może być dla syna wychowawczynią, dostrzegał również Klemens ${ }^{50}$, o czym świadczy jego wypowiedź, w której powołuje się na przykład Arete, córki Arystypa z Cyreny (ok. 435-366), ucznia Sokratesa i założyciela szkoły filozoficznej, która wychowywała swego syna Arystypa, zwanego Metrodidaktos, co oznacza według naszego Autora, „uczonego przez matkę"51.

$\mathrm{W}$ procesie wychowawczym ważną rolę odgrywa przede wszystkim ojciec. Dla Hieronima takim przykładem jest ojciec mówcy rzymskiego, Hortensjusza (114-50), który ucząc swego syna wymowy, swym przykładem wywierał wpływ na jego postępowanie ${ }^{52}$. Znaczenie wychowawcze ojca w rodzinie dostrzegał także Klemens, który przyznawał mu pod tym względem pierwszorzędną rolę, zwłaszcza wobec syna. Pisząc bowiem o gnostyku, a więc prawdziwym chrześcijaninie, zauważa:

„gnostyk okazuje się prawdziwym mężczyzną nie przez wybór dla siebie życia samotnego, lecz tym «zwycięża mężów», że troszcząc się o małżeństwo, płodzenie dzieci oraz opiekę nad domem jednocześnie nie wykazuje wrażliwości ani na rozkosz, ani na ból. Mimo kłopotów o dom nie daje się oderwać od miłości do Boga, zwycięsko wychodząc z wszelkiej próby, na jaką tylko wystawia go sytuacja ojca rodziny, męża, pana służby i właściciela majętności”" ${ }^{53}$.

Porównując go z mężczyzną niezamężnym, podkreśla, że choć ten:

„przewyższa go w zakresie własnego zbawienia, to jednak ojciec przewyższa

\footnotetext{
${ }^{45}$ Por. Hieronymus, Epistola 107, 13, PL 22, 877.

${ }^{46}$ Por. tamże 107, 9, PL 22, 875.

${ }^{47}$ Por. tamże 107, 11, PL 22, 876, ŹMT 61, 156.

${ }^{48}$ Por. tamże 107, 4, PL 22, 871-872; Quintilianus, Institutio oratoria I 1, 6.

${ }^{49}$ Por. Hieronymus, Epistola 125, 6, PL 22, 1075.

${ }^{50}$ Por. Clemens Alexandrinus, Stromata II 23, 141, 2.

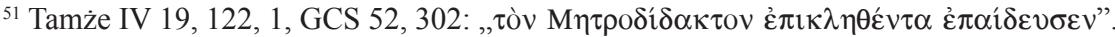

${ }^{52}$ Por. Hieronymus, Epistola 107, 4, PL 22, 871-872.

${ }^{53}$ Clemens Alexandrinus, Stromata VII 12, 70, 7, GCS 17, 51, Niemirska-Pliszczyńska II 274.
} 
go swą pieczą o życie całej rodziny ucieleśniając nieudolnie i w miniaturze odbicie prawdziwej Opatrzności" ${ }^{54}$.

Dla Klemensa ojcem jest więc ten, który kształci i wychowuje, ponieważ „mądrość z samej swej natury ujawnia tendencję do udzielania się i ludzi buduje" ${ }^{55}$, co oznacza, że w przekonaniu Aleksandryjczyka „ojciec jest pierwszą przyczyną sprawczą procesu nauczania"56. To wychowywanie potomstwa oraz jego kształcenie musi się jednak, zdaniem Klemensa, odbywać „w Panu i zgodnie z wolą Logosu" ${ }^{57}$. Ta myśl obecna jest także w innym miejscu, w którym Autor przyznaje:

„Ojciec uczy swego syna (jeśli jest to potomek męski) i nie daje się rozdzielić z przykazaniami Bożymi i nadzieja, stale przy tym wyraża Bogu swą wdzięczność, podobnie jak owe istoty, które wedle alegorycznego opowiadania Izajasza (Iz 6, 2), sławiły Boga"58.

Już w świetle powyższych wypowiedzi pod adresem matek i ojców, można stwierdzić, że obaj nasi Autorzy szczególny nacisk kładą na to, aby rodzice, jak to precyzuje Hieronim, byli osobami wierzacymi ${ }^{59}$, oraz stanowili przykład dla dziecka tak, aby ich postępowanie, które bardziej uczy niż wypowiadane słowa, nie prowadziło go do grzechu ${ }^{60}$. To oznacza, że odpowiedzialność, jak podkreśla Hieronim, za dorosłe i samodzielne dzieci spada na rodziców, szczególnie zaś za niedorosłe ${ }^{61}$. Ta odpowiedzialność zwiększa się zwłaszcza wtedy, gdy rodzice, na mocy ślubu, postanowili oddać córkę na służbę Bogu ${ }^{62}$.

Na podstawie lektury analizowanych pism obu Autorów możemy się przekonać, że Hieronim, w odróżnieniu od Klemensa, poszerza zakres odpowiedzialności za wychowanie, ponieważ włącza w jego proces, obok matki i ojca, także krewnych. Potwierdzenie tego znajdujemy w skierowanej do Lety radzie, aby swą córkę Paulę oddała wpierw babce, noszącej to samo imię, oraz ciotce Eustochium, przebywającym w klasztorze, które winny być dla niej przykładem do naśladowania; za nimi też córka powinna tęsknićc ${ }^{63}$. Według bowiem naszego Autora, Paula przebywając w towarzystwie swej ciotki, bę-

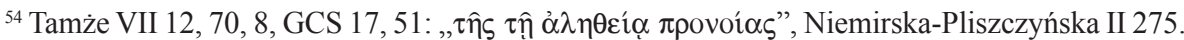

${ }^{55}$ Tamże I 1, 1, 3, GCS 52, 3, Niemirska-Pliszczyńska I 2.

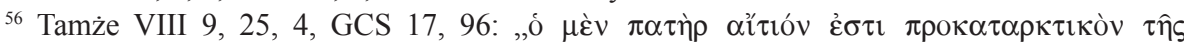
$\mu \alpha \theta \eta ் \sigma \varepsilon \omega \varsigma ”$, Niemirska-Pliszczyńska II 330.

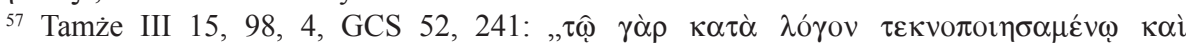

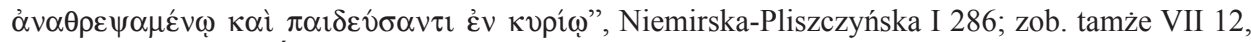
80, 4; Drączkowski, Świętość malżeństwa i rodziny, s. 123.

${ }^{58}$ Clemens Alexandrinus, Stromata VII 12, 80, 4, GCS 17, 57, Niemirska-Pliszczyńska II 282.

${ }^{59}$ Por. Hieronymus, Epistola 14, 3, PL 22, 349.

${ }^{60}$ Por. Hieronymus, Epistola 107, 9, PL 22, 875; zob. L. Cignelli, La „Famiglia-modello” nella Chiesa patristica, „Liber Annus” 32 (1982) 177; Stępniewska, Wychowanie rodzinne dziewczat, s. 163.

${ }^{61}$ Por. tamże 107, 6, PL 22, 873.

${ }^{62}$ Por. tamże 107, 6, PL 22, 873-874.

${ }^{63}$ Por. tamże 107, 13, PL 22, 877. 
dzie miała w niej towarzyszkę świętości: będąc z nią razem winna na nią patrzeć, kochać, podziwiać jako tę, „której mowa, strój i gesty są nauką cnót”64.

Życzeniem Hieronima wypowiedzianym z kolei wobec babci, było to, aby starała się w swej wnuczce szukać tych cech, które kiedyś zaszczepiła swej córce, ponieważ, jak czytamy, „wychowywała, pielęgnowała i nauczała dziewice" ${ }^{5}$. Dziecko wychowywane w takim klimacie, jak podkreśla Hieronim, będzie człowiekiem szczęśliwym, ponieważ dzięki „cnotom babki i ciotki” stanie się szlachetniejsze świętością, aniżeli pochodzeniem ${ }^{66}$.

W tym procesie wychowawczym swoją rolę pełnił także dziadek, który pomimo że sam jeszcze daleki był od wiary ${ }^{67}$, winien ze swą wnuczką, zdaniem Strydończyka, bawić się i otaczać ją troskliwymi pieszczotami ${ }^{68}$.

W wychowywaniu dziecka, a szczególnie dziewczynki, jak dowiadujemy się z tego samego listu Hieronima, pomagała także piastunka (nutrix), wobec której Autor stawiał również wysokie wymagania moralne. Nie może to więc być, w jego przekonaniu, osoba obciążona nałogiem pijaństwa ${ }^{69}$, popełniająca grzechy rozpusty, ani też zajmująca się plotkarstwem, ale kobieta skromna ${ }^{70}$.

Z wypowiedzi naszego Autora wynika także, że wychowawczynią dziewczynki powinna być kobieta głęboko wierząca, poważna, charakteryzująca się dobrymi obyczajami i wstydliwością ${ }^{71}$ oraz powściągliwością w mowie ${ }^{72}$. Będzie bowiem uczyć przykładem swego życia i przyczyni się do rozbudzenia u dziecka wiary, czego wyrazem będą wdrażane w jego życie różne praktyki religijne $^{73}$. Te zalety opiekunki sprawią też, że nie tylko wspomniana już w tym miejscu młodziutka Paula, ale także Pakatula, na temat której czytamy w liście do Gaudencjusza, ukształtują swe umysły w cnocie ${ }^{74}$. Wychowawczyni, spełniająca te kryteria, winna też umieć prowadzić z dzieckiem zajęcia praktyczne tak, by dziewczynce od wczesnych lat przekazać tego rodzaju umiejętności ${ }^{75}$.

Z listów Hieronima dowiadujemy się również tego, że bardzo ważną rolę w kształceniu, zwłaszcza synów, odgrywają nauczyciele, którym należy sta-

\footnotetext{
${ }^{64}$ Tamże: „cuius et sermo, et incessus, et habitus, doctrina virtutum est”, ŹMT 61, 158.

${ }^{65}$ Tamże: „quae longo usu didicit nutrire, servare, docere virgines”.

${ }^{66}$ Por. tamże 107, 13, PL 22, 877: „quae per aviae amitaeque virtutes nobilior est sanctitate, quam genere".

${ }^{67}$ Por. tamże 107, 1, PL 22, 868.

${ }^{68}$ Por. tamże 107, 4, PL 22, 872; zob. Stępniewska, Wychowanie rodzinne dziewczat, s. 155.

${ }^{69}$ Por. tamże 107, 4, PL 22, 872: „Nutrix ipsa non sit temulenta”; tamże 128, 3, PL 22, 1098: „,non multo vino dedita”.

${ }^{70}$ Por. tamże 107, 4, PL 22, 872: „non lasciva, non garrula: habeat modestam gerulam”; tamże 128, 3, PL 22, 1098: „otiosa atque verbose”.

${ }^{71}$ Por. tamże 107, 4, PL 22, 872: „nutricium gravem”.

${ }^{72}$ Por. Hieronymus, Epistola 128, 4, PL 22, 1098.

${ }^{73}$ Por. Hieronymus, Epistola 107, 9, PL 22, 875.

${ }^{74}$ Por. Hieronymus, Epistola 128, 3, PL 22, 1098: „quae animum puellarem ad virtutem instituant".

${ }^{75}$ Por. Hieronymus, Epistola 128, 3, PL 22, 1098.
} 
wiać wysokie wymagania, bacząc by były nimi osoby odpowiednie wiekiem, życiem i wykształceniem. Jako przykład człowieka spełniającego te kryteria przywołuje osobę filozofa Arystotelesa, który uczył i wychowywał syna króla Filipa Macedońskiego ${ }^{76}$ - Aleksandra Wielkiego (356-323), w przeciwieństwie do jego poprzedniego wychowawcy Leonidesa, którego wady przejął i później nie mógł się oduczyć ów „potężny król i zdobywca świata”77.

Podsumowując w tym miejscu refleksje obu Autorów, a zwłaszcza Hieronima, na temat osób odpowiedzialnych za wychowanie młodego człowieka, należy podkreślić, iż Strydończyk najwięcej słów pochwały wypowiedział pod adresem tych, którzy podjęli się w sposób odpowiedzialny kierować procesem wychowawczym. Potwierdza to jego list adresowany do Demetriady, w którym z uznaniem wypowiada się pod adresem matki Juliany i babki Proby, za wychowanie swej córki i wnuczki ${ }^{78}$, ponieważ, jak podkreśla w liście do Salwiny, „wielką zasługą w oczach Bożych jest dobrze wychować dzieci" na co także zwracał uwagę Klemens, gdy pisał:

„dla tych, którzy z wolą Logosu płodzą dzieci, wychowują je i kształcą w Panu, oczekuje określona zapłata ${ }^{80}$.

Wszelkie natomiast przejawy zaniedbania matki wobec dziecka, Hieronim nie tylko poddawał krytyce ${ }^{81}$, ale brak troski o rozwój duchowy dziecka poświęconego Bogu nazywał świętokradztwem ${ }^{82}$, zaś za zbrodnię uważał fakt nie ochrzczenia dziecka ${ }^{83}$. Hieronim wypowiadając te słowa miał jednak na uwadze możliwość, że może mieć miejsce i taka sytuacja, kiedy to matka nie czuje się na siłach, aby sprostać trudnościom w wychowaniu córki. Wtedy to rozwiązaniem tego problemu jest, jego zdaniem, oddanie córki do klasztoru ${ }^{84}$.

\section{CZŁOWIEK PODMIOTEM PROCESU WYCHOWAWCZEGO}

Obaj autorzy, poruszając problem wychowania człowieka oraz osób za nie odpowiedzialnych, musieli także wypowiedzieć się na temat dziecka, rozumianego jako podmiot procesu wychowawczego. Nie zawsze jednak po-

${ }^{76}$ Por. Hieronymus, Epistola 107, 4, PL 22, 871: „Magister probae aetatis et vitae, eruditionisque est eligendus"; zob. Quintilianus, Institutio oratoria I 1, 23.

${ }^{77}$ Hieronymus, Epistola 107, 4, PL 22, 872, ŹMT 61, 152.

${ }^{78}$ Por. Hieronymus, Epistola 130, 2, PL 22, 1108.

${ }^{79}$ Hieronymus, Epistola 79, 7, PL 22, 728: „Non est parvi apud Deum meriti, bene filios educare", ŹMT 55, 240.

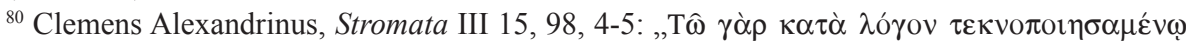

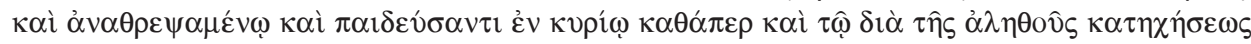

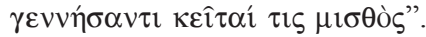

${ }^{81}$ Por. Hieronymus, Epistola 127, 4, PL 22, 1090.

${ }^{82}$ Por. Hieronymus, Epistola 107, 6, PL 22, 784: „sacrilegii reus est”.

${ }^{83}$ Por. tamże 107, 6, PL 22, 784: „scelus referri ad eos, qui dare noluerint”.

${ }^{84}$ Por. tamże 107, 13, PL 22, 877: „Nutriatur in monasterio”. 
zytywnie zapatrywano się na wydawanie na świat potomstwa. Zauważa to przede wszystkim Klemens, który przytacza niektóre poglądy przedstawicieli świata greckiego, potwierdzające taką postawę ${ }^{85}$. Mówiąc zaś to, powołuje się na wypowiedzi przedstawiciela jońskich filozofów przyrody, Heraklita z Efezu (ok. 544-484), i uważa także, że tę opinię podzielał późniejszy filozof, lekarz, przyrodnik i poeta grecki Empedokles z Agrigentum (ok. 495-435) ${ }^{86}$, a nawet, jego zdaniem, doszukać się jej można także w wypowiedziach Sybilli i poety Homera (VIII w. prz. Chr.) $)^{87}$. Tenże Aleksandryjczyk przytacza też poglądy poety elegijnego, Teognisa z Megary (VI w. prz. Chr.), który narodziny człowieka miał uważać za coś złego ${ }^{88}$, a także tragika greckiego, Eurypidesa (ok. 485-406), który każe wysławiać człowieka zmarłego i zastanawia się, czy życie jest śmiercią, czy życiem jest śmierć ${ }^{89}$. Tenże tragik utrzymywał również, że czymś lepszym dla człowieka jest nie rodzić się, aniżeli żyć. Rodzenie bowiem, jego zdaniem, sprawia ból, który się potęguje gdy się okaże, że urodzone dziecko było złym dzieckiem ${ }^{90}$. Stąd też biorąc pod uwagę te trudności, człowiek nie powinien wydawać na świat potomstwa ${ }^{91}$. Klemens kontynuując swą refleksję o powstrzymywaniu się od wydawania na świat potomstwa, informuje, iż z tych samych powodów, o których wypowiadał się już Eurypides, prawdopodobnie również pitagorejczycy powstrzymywali się od życia płciowego: żenili się, ale tylko dla spłodzenia potomstwa, potem zaś „wzywali do wstrzymania się od rozkoszy seksualnej"92.

Analizując Kobierce Aleksandryjczyka możemy się przekonać, iż odwoływał się on także do dialogu filozoficznego Fedon, autorstwa filozofa Platona (427-347) i wnioskował, że ten uczeń Sokratesa stał na stanowisku, iż przyczyną największych nieszczęść jest przyjście człowieka na świat ${ }^{93}$. Komentując tę opinię Klemens dochodzi do wniosku, że Platon już przed gnostykiem Marcjonem (I w.) negatywnie odnosił się do seksualnego współżycia, którego skutkiem jest poczęcie człowieka ${ }^{94}$. Na potwierdzenie tego Aleksandryjczyk,

${ }^{85}$ Por. Clemens Alexandrinus, Stromata III 3, 22, 1.

${ }^{86}$ Por. tamże III 3, 14, 1-2, GCS 52, 201-202 (ich wypowiedzi): Heraclitus, frgm. 20, ed. H. Diels: Vorsokratiker I 155; Empedocles, frgm. 118, 124 i 125, ed. H. Diels: Vorsokratiker I 359, 361 i 362, Niemirska-Pliszczyńska I 236-237.

${ }^{87}$ Por. Clemens Alexandrinus, Stromata III 3, 14, 3, GCS 52, 202: Oracula Sibyllina frgm. 1, 1; Homerus, Odyssea XVIII 130.

${ }^{88}$ Por. Clemens Alexandrinus, Stromata III 3, 15, 1.

${ }^{89}$ Por. tamże III 3, 3, 15, 2-3, GCS 52, 202, Niemirska-Pliszczyńska I 236; zob. Euripides, Cresphontes frgm. 449, w: Tragicorum Graecorum Fragmenta (= TGF), vol. 5, ed. R. Kannicht, Göttingen 2004, 498; Euripides, Polyidus frgm. 638, TGF vol. 5, s. 560.

${ }^{90}$ Clemens Alexandrinus, Stromata III 3, 22, 2; Euripides, Frgm. inc. 908, TGF vol. 5, s. 652-653.

${ }^{91}$ Por. Clemens Alexandrinus, Stromata III 3, 22, 3; tamże III 3, 23, 1- 2; zob. Euripides, Adespota 111, TGF vol. 5, s. 862; Iphigenia in Aulida 161-163; Antiope frgm. 211, TGF, vol. 5, s. 423; Supplices 269.

${ }^{92}$ Clemens Alexandrinus, Stromata III 3, 24, 1, GCS 52, 206, Niemirska-Pliszczyńska,I 242.

${ }^{93}$ Por. tamże III 3, 17, 4; Plato, Phaedo 66B; 69C.

${ }^{94}$ Por. Clemens Alexandrinus, Stromata III 3, 18, 3. 
zmieniając nieco tekst Platona, podkreśla, iż ten filozof nie tylko na pierwszym miejscu stawiał „rozkosz umysłowo interesującej rozmowy”95 ale także unikał obcowania seksualnego ${ }^{96}$, będąc przekonanym, że narodziny człowieka są czymś złym ${ }^{97}$. Kontynuując swą refleksję na temat stosunku niektórych przedstawicieli przedchrześcijańskiego świata starożytnego do pojmowania życia, Klemens cytuje także rozważania ojca historii, Herodota z Halikarnasu (ok. 485-425), który ustami ateńskiego męża stanu i poety, Solona (ok. 640-560) miał twierdzić, iż każdy człowiek jest trafem losu ${ }^{98}$. Przypomina on również opowiadanie Herodota o dwóch braciach - Kleobisie i Bitonie, którzy kochali bardzo swą matkę i w czasie świąt Hery pragnęli ją zawieść do świątyni zaprzęgając się do wozu. Matka prosiła bogów dla nich o największe szczęście. Oni jednak zesłali im we śnie śmierć. Klemens komentując to opowiadanie uważa, że gani ono urodzenie człowieka, a pochwala jego śmierć oraz uzupełnia je stwierdzeniem Homera, iż los człowieka podobny jest do nietrwałych liści ${ }^{99}$.

Dokonując oceny powyższych poglądów nasz Autor jest zdania, że nie tylko grzeszą przeciw Bogu ci, co ,pod zbożnym pretekstem przestrzegają wstrzemięźliwości [...], pouczaja, że nie należy zawierać małżeństwa i płodzić dzieci, gdyż w ten sposób sprowadza się na świat dla poszczególnych osób nieszczęście, a zwłaszcza śmierć" ${ }^{100}$, ale też dopuszczają się bluźnierstwa „przeciw Bogu i misterium stworzenia świata” ci, co spotwarzają narodziny

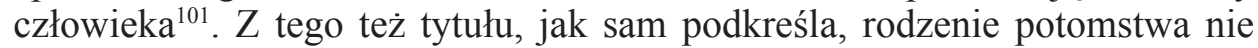
może być przez nikogo uważane za przekleństwo ${ }^{102}$ i dlatego należy odrzucić błędne poglądy reprezentowane przez takich gnostyków, jak Kasjan, Marcjon, Walentyn, oraz doketyzm ${ }^{103}$.

Lektura dzieła Klemensa nie ogranicza się jednak tylko do negatywnej oceny przytoczonych przez Autora poglądów starożytnych autorów, ale zawiera także naukę podkreślającą prawdę, że wydawanie na świat potomstwa winno dokonywać się z wielką roztropnością. Aleksandryjczyk bowiem tłumacząc

${ }^{95}$ Tamże III 3, 18, 4, GCS 52, 204; zob. Plato, Respublica I 328D.

${ }^{96}$ Por. Clemens Alexandrinus, Stromata III 3, 4; zob. Plato, Respublica I 329C.

${ }^{97}$ Por. Clemens Alexandrinus, Stromata III 3, 19, 1; zob. Plato, Phaedo 62B.

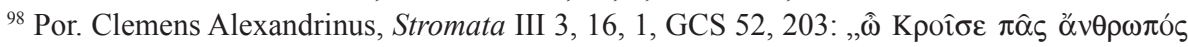

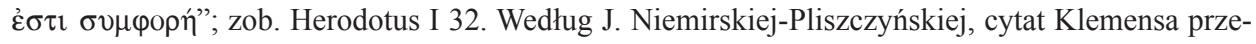
kazany w metrum jambicznym, różni się od cytatu Herodota pisanego prozą zob. Niemirska-Pliszczyńska I 328, przypis 24.

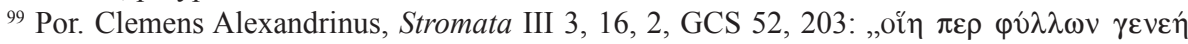

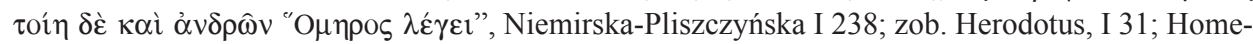
rus, Ilias VI 146.

${ }^{100}$ Clemens Alexandrinus, Stromata III 6, 45, 1, GCS 52, 216-217, Niemirska-Pliszczyńska I 254-255.

${ }^{101}$ Por. tamże III 17, 102, 2, GCS 52, 243, Niemirska-Pliszczyńska I 289.

${ }^{102}$ Por. tamże III 15, 98, 5.

${ }^{103}$ Por. tamże III 17, 102, 3. 
przepisy Prawa Starego Testamentu głosi tezę, iż ono chcąc zaprowadzić porządek moralny nakazuje, by ludzie decydowali się na zawieranie roztropnych małżeństw i w tym też duchu płodzili dzieci ${ }^{104}$. Biorąc to zaś pod uwagę, małżeństwo nie powinno być zawierane z powodu namiętności, gdyż człowiek nie jest dzieckiem ,pożądania, ale woli”"105. Tak więc ten, kto się ożenił w celu wydania na świat potomstwa, winien ćwiczyć w sobie cnotę powściagliwości, „aby nie tyle z pożądania własnej żony, którą winien kochać, ile z uświęconej i roztropnej woli płodził dzieci" ${ }^{106}$. Innymi słowy, Autor nasz wypowiadając te prawdy, stara się przestrzec przed niebezpieczeństwem popadania $\mathrm{w}$ dwie skrajności, polegające na tym, że jedni, pod pozorem trudności małżeńskich, powstrzymują się od małżeństwa popadając w nienawiść wobec ludzi, a drudzy, którzy tkwiąc w małżeństwie ,zażywają w nim wszelkich rozkoszy upodabniając się do zwierząt" ${ }^{107}$. Stąd też dla Klemensa bezdzietność jest dla małżonków wielkim brakiem ${ }^{108} \mathrm{i}_{\text {bólem }}{ }^{109}$.

Porównując treść listów Hieronima z tym, co naucza Klemens, musimy jednak zauważyć, iż Hieronim nie dokonuje w nich tak szczegółowego przeglądu i oceny poglądów, dotyczących zasadności lub jej braku, gdy chodzi o wydawanie na świat potomstwa, ale jak to wynika $\mathrm{z}$ jego wypowiedzi, dziecko jest dla niego darem Bożym ${ }^{110}$, co można również $\mathrm{w}$ sposób pośredni wywnioskować z nauczania Klemensa. Obaj jednak Autorzy zgodni są co do tego, że zrodzone przez rodziców dziecko powinno być, jak to precyzuje Klemens, poddane procesowi wychowania i kształcenia $\mathrm{w}$ Panu ${ }^{111}$.

W odróżnieniu natomiast od Klemensa, Hieronim wyraźnie zaznacza, że dziecko (tu ma na myśli małą Pakatulę) nie wszystko rozumie, co się do niego mówi ${ }^{112}$. Pomimo tego jednak ten proces wychowawczy, jak to wynika z kolei z postawionego przez Strydończyka pytania, winien rozpocząc się od najwcześniejszych lat, ponieważ dziecko będąc osobą niedorosłą i słabą ,nie zdaje sobie sprawy z różnicy pomiędzy dobrem a złem" "113, a będąc jeszcze dzieckiem, jak czytamy dalej, rozumuje jak dziecko, aż do czasu osiągnięcia wieku rozumnego, kiedy to stanie się odpowiedzialne za swe postępowanie ${ }^{114}$. Te

104 Por. tamże III 6, 46, 2.

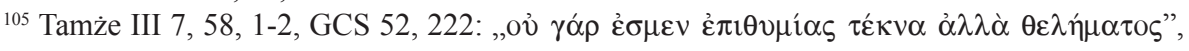
Niemirska-Pliszczyńska I 262.

106 Tamże.

107 Tamże III 9, 67, 2, GCS 52, 226, Niemirska-Pliszczyńska I 267.

108 Por. tamże II 139, 5 - 140, 1; zob. P. Blomenkamp, Erziehung, RACh VI 526.

${ }^{109}$ Por. Clemens Alexandrinus, Stromata III 9, 67, 1.

${ }^{110}$ Por. Hieronymus, Epistola 107, 3, PL 22, 870; zob. Blomenkamp, Erziehung, RACh VI 526.

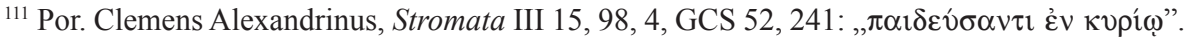

112 Por. Hieronymus, Epistola 128, 1, PL 22, 1096.

${ }^{113}$ Hieronymus, Epistola 107, 6, PL 22, 873: „quanto magis lactens et fragilis, quae iuxta sententiam Domini, ignorat dexteram et sinistram, id est, boni et mali differentiam”; zob. Stępniewska, Wychowanie rodzinne dziewczat, s. 154.

${ }^{114}$ Por. tamże. W tym miejscu Autor czyni aluzję do symboliki związanej literą pitagorejską Y, 
słowa, wypowiedziane przez Hieronima, oznaczają że należy czynić wszystko, aby dziecko poddało się temu wychowawczemu procesowi. Potwierdza to tym razem i Klemens, który uczy, że „każdy kto pozwala się wychowywać, przez posłuszeństwo w stosunku do wychowującego, staje się jego synem" 115 . Nie tylko więc, naszym zdaniem, dla Klemensa istotnym jest synostwo pochodzące ze zrodzenia fizycznego, ale także drugie, tym razem duchowe ,usynowienie" człowieka, podczas dokonującego się procesu wychowawczego, co, jak już mogliśmy się przekonać, potwierdzał ten Autor, gdy mówił, że ojcem jest ten, którzy kształci.

\section{PRZEDMIOT FORMACJI}

Ostatni punkt naszego opracowania stanowić będzie próbę odpowiedzi na pytanie, co powinno być przedmiotem wychowania młodego człowieka. Z lektury pism naszych autorów wynika, że szczególną wagę przywiązywali oni do formacji religijnej, moralnej i intelektualnej. W takiej też kolejności przybliżymy to zagadnienie.

1. Formacja religijna. Religijna formacja młodego człowieka, jak to wynika z wypowiedzi Hieronima, rozpoczyna się od momentu przyjęcia chrztu świętego ${ }^{116}$. Celem tej formacji, jak zaznacza ten Autor, jest pogłębienie duchowe człowieka, polegające na uczeniu się i słuchaniu tego co należy do bojaźni Bożej ${ }^{117}$, wzrastaniu „w mądrości, w latach i w łasce u Boga i ludzi” (Łk 2, $52)^{118}$, a więc takie ukształtowanie duszy „by stała się ona świątynią Pana" ${ }^{119}$, niejako „miejscem” Jego zamieszkiwania w człowieku. Tego trudu podjęła się, jak informuje nas Strydończyk, Paula wobec swej córki Eustochium, którą poświęconą Chrystusowi pozostawiła, jak czytamy, „bogatą w łaskę wiary”" 120 .

Ta prawda o znaczeniu, jakie należy przywiązywać do formacji religijnej, prowadzącej do osobistej świętości, obecna jest również w Kobiercach Klemensa, który powołując się na Ewangelię św. Jana $(\mathrm{J} 3,6)$ podkreśla, że słowa tego Ewangelisty mówiące o tym, że „to co się rodzi z Ducha, jest Duchem”, odnosi się „nie tylko do urodzin, lecz i do nauczania”121. Stąd więc, powołując

która wyobrażała życie ludzkie. Jedno ramię tej litery oznaczało cnotę, zaś drugie występki; zob. także Persius, Satirae 3, 56-67; Ausonius, Idyllio 16.

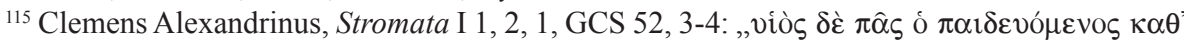

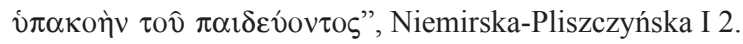

116 Por. Hieronymus, Epistola 107, 6, PL 22, 873.

117 Por. tamże 107, 4, PL 22, 871: „Nihil aliud discat audire, nihil loqui, nisi quod ad timorem Dei pertinet".

${ }^{118}$ Tamże 107, 7, PL 22, 874, ŹMT 61, 154.

119 Tamże 107, 4, PL 22, 871: „Sic erudienda est anima, quae futura est templum Dei”, ŹMT $61,151$.

${ }^{120}$ Hieronymus, Epistola 108, 2, PL 879, ŹMT 61, 160.

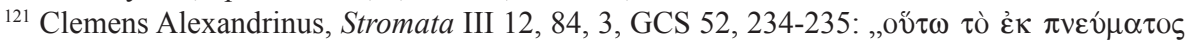


się z kolei na nauczanie św. Pawła $(1$ Kor 7,14$)$ zauważa, że świętość staje się udziałem dzieci, „które są miłe Bogu, gdyż słowa Pańskie zaręczyły z Nim ich dusze"122. Innymi słowy, Aleksandryjczyk dzieląc się tymi przemyśleniami stara się przekonać, że dusza młodego człowieka poddana formacji religijnej jest poprzez słowa Pana uświęcona jako oblubienica Chrystusa ${ }^{123}$. To więc oznacza, że wychowywanie potomstwa, zdaniem Klemensa, dokonywać się musi ,,w Panu i zgodnie z wolą Logosu”" 24 .

Ta myśl znajduje, naszym zdaniem, swe praktyczne zastosowanie u Hieronima, który przypomina adresatce swego listu, że nie należy dziecku dawać do ręki apokryfów, ze względu na obecność błędów dogmatycznych, ale w ich miejsce zalecać pisma biskupa Kartaginy -Cypriana (†258), listy biskupa Aleksandrii - Atanazego $(† 373)$, oraz pisma biskupa Poitiers - Hilarego $(\dagger 367)^{125}$. Oprócz lektury tych autorów, wielką wagę przywiązywał Strydończyk przede wszystkim do zapoznawania dziecka z Pismem Świętym ${ }^{126}$, z którego każdego dnia winno ono odrabiać jakieś zadanie ${ }^{127}$. To właśnie zamiast klejnotów i jedwabi Biblia, jak przekonuje Autor, winna być ukochana przez dziecko. Mówiąc to podkreśla jednak, aby nie tyle pokochało zewnętrzny wygląd Pisma Świętego, a więc malowidła ze złota i purpury na babilońskiej skórze, lecz jego „poprawną i z erudycją dla dobra wiary wykonaną interpunkcję (distinctio)"128.

Hieronim, jak można się przekonać czytając jego listy, nie tylko ograniczał się do zachęty, by studiować Pismo Swiete, ale podał niemal cały program i kolejność przebiegu tego studium i cel, jakiemu ma ono służyć. Tak więc $\mathrm{w}$ pierwszej kolejności córka adresatki listu powinna uczyć się Psałterza, sycąc się „słodyczą psalmów"129, odnajdując, jak czytamy, w tych pieśniach rozrywkę. Z kolei przypowieści Salomona winny ją przygotowywać do życia, a lektura ksiąg Eklezjastesa winna ją uzdolnić do pogardzania rzeczami tego świata, zaś w księdze Joba winna szukać przykładów męstwa i cierpliwości. To studium nie może też pomijać ksiąg Nowego Testamentu. Dopiero jednak w końcowej fazie Autor proponuje, by dziecko zapoznało się z księgą Pieśni nad Pieśniami, już bez obawy, jak czytamy, niezrozumienia duchowego sensu tego epitalamium, które mogłoby ją zranić, gdyby od niego zaczęła lekturę ${ }^{130}$.

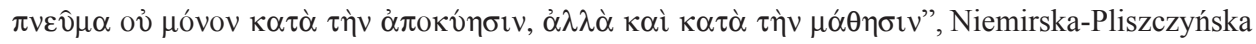
I 278.

${ }^{122}$ Tamże.

${ }^{123}$ Por. A. Lumpe - H. Karpp, Eltern, RACh IV 1208.

${ }^{124}$ Clemens Alexandrinus, Stromata III 15, 98, 4, GCS 52, 241; tamże VII 12, 80, 4; zob.

Drączkowski, Świętość matżeństwa i rodziny, s. 123.

${ }^{125}$ Por. Hieronymus, Epistola 107, 12, PL 22, 877.

${ }^{126}$ Por. tamże 107, 7, PL 22, 874.

${ }^{127}$ Por. tamże 107,9 , PL 22, 875.

${ }^{128}$ Por. tamże 107, 12, PL 22, 876. Hieronimowi chodzi o znaki krytyczne, które ułatwiają właściwe zrozumienie tekstu.

${ }^{129}$ Por. tamże 107, 4, PL 22, 871: „Psalmis dulcibus imbuatur”.

${ }^{130}$ Por. tamże 107, 12, PL 22, 876. 
Autor ten z uznaniem wypowiada się o matce Pauli, która nakłaniała go, by był dla niej i dla jej córki przewodnikiem w lekturze Starego i Nowego Testamentu ${ }^{131}$; podzielał także radość z tego, że dziewczynka, ,już w kołysce umiała śpiewać «Alleluja»" 132 , pochwalał za to dorosłą już Blezylę, która aż do swej śmierci czytała księgi proroków i Ewangelię ${ }^{133}$.

Do formacji religijnej dziecka - kontekst mówi tu jedynie o dziewczynce - przyczynia się także jego obecność wraz z matką w kościele, co przypominać ma takie samo wydarzenie z życia Chrystusa (Łk 2, 41-50) ${ }^{134}$. Z kolei w towarzystwie opiekunki i z jej udziałem winny mieć miejsce również inne praktyki religijne, jak: odmawianie i to często w nocy psalmów, śpiewanie porannych hymnów, czy też stawanie „w szeregu o godzinie trzeciej, szóstej i dziewiątej oraz składanie ofiary wieczornej przy zapalonej świeczce" ${ }^{135}$. Tak też postępowała na przykład zmarła córka Pauli, Blezyla, która będąc mężatką odznaczała się wyjątkową gorliwością w modlitwie ${ }^{136}$. Ta praktyka codziennej modlitwy, której wyrazem jest lektura i śpiew psalmów, winna mieć miejsce również po jedzeniu ${ }^{137}$.

W przekonaniu Hieronima, do kształtowania formacji religijnej dziecka przyczyniają się nie tylko czuwania, ale również posty, przy pomocy których umartwia się ciało, a przez praktykowaną wstrzemięźliwość pokonuje się pożądliwośćc ${ }^{138}$. Ten post jednak winien być, zwłaszcza gdy chodzi o dziewczynkę, stosowany z umiarem, ponieważ w młodym wieku należy unikać długich i nieumiarkowanych, trwających tygodniami postów, polegających również na rezygnacji ze spożywania owoców i z dodawania oliwy do pokarmów, ale „ma tak jeść, by jej starczyło sił na później"139.

Głęboka i pozbawiona błędów wiara, zaszczepiana przez rodziców dziecku od najmłodszych lat, ma je usposobić do mężnego jej wyznawania. Potwierdzenie tego znajdujemy u Hieronima, który uważa, że skoro rodzice są osobami prawdziwie wierzącymi w Chrystusa, to winni oni wspierać także swe dzieci zamierzające walczyć dla Niego ${ }^{140}$. Nie dziwi więc go fakt, że na przykład wspominana Paula nie tylko tęskniła za swą ojczyzną, ale także sta-

${ }^{131}$ Por. Hieronymus, Epistola 108, 26, PL 22, 902.

132 Tamże.

${ }^{133}$ Por. Hieronymus, Epistola 39, 1, PL 22, 466: „aut Prophetam, aut Evangelium semper in manibus tenebat".

${ }^{134}$ Por. Hieronymus, Epistola 107, 7, PL 22, 874; tamże 107, 9, PL 22, 875; zob. L. Cignelli, La „Famiglia-modello” nella Chiesa patristica, „Liber Annus” 32 (1982) 177.

${ }^{135}$ Hieronymus, Epistola 107, 9, PL 22, 875, ŹMT 61, 155.

${ }^{136}$ Por. Hieronymus, Epistola 39, 1, PL 22, 465: „orandi instantiam”.

${ }^{137}$ Por. Hieronymus, Epistola 107, 10, PL 22, 875-876.

${ }^{138}$ Por. tamże 107, 11, PL 22, 876: „Si enim vigiliis et jejuniis macerat corpus suum, et in servitutem redigit; si flammam libidinis et incentiva ferventis aetatis extinguere cupit continentiae frigore", ŹMT 61, 157.

${ }^{139}$ Por. tamże 107, 10, PL 22, 875-876, ŹMT 61, 156.

${ }^{140}$ Por. Hieronymus, Epistola 14, 3, PL 22, 349. 
rała się dowiadywać, czy jej syn i synowa oraz wnuczka ,zrywają ze światem i służą Chrystusowi”"141.

Wyrazem głębokiej formacji religijnej dziecka, jak to potwierdzają listy Hieronima, jest takie jej ukierunkowanie, aby ono kiedyś obrało stan dziewictwa poświęconego Bogu. W taki sposób postępowała wobec swego dziecka Paulina, której zamiarem nie było wypełnianie błogosławieństwa Bożego wypowiedzianego w Księdze Rodzaju $(1,28)$, ani też obowiązku małżeńskiego, ale, jak czytamy, ,życzyła sobie dzieci, by mogła rodzić dziewice Chrystusowi” ${ }^{142}$. Z tego też powodu Strydończyk zachęca także ojca Furii, byłego konsula i patrycjusza, aby ten cieszył się, że „zrodził córkę dla Chrystusa, a nie dla świata”"143.

Z kolei osobisty wybór takiej właśnie drogi życia, jak czytamy w liście adresowanym do Demetriady, napełniał radością jej matkę Julianę ${ }^{144}$, jak również babkę Probę, które ściskały ją i płakały z radości przyznając, że postapiła ona zgodnie z ich wobec niej planami, oraz cieszyły się, że „dziewica swym dziewictwem znakomitą rodzinę uczyniła jeszcze znakomitszą". W ich też przekonaniu ta decyzja „Zwiększyła chwałę rodu i złagodziła ból po spaleniu Rzymu"145. Wyrazem tej radości było to, że tak matka jak i babka ofiarowały Demetriadzie wszystko, co miała otrzymać z okazji małżeństwa. Uczyniły to też z tego powodu, gdyż nie chciały, by ,stała się krzywda Oblubieńcowi [= Chrystusowi]; pragnęły, by tak wyposażona ,dawnymi dostatkami, poszła do Oblubieńca", aby tym, co otrzymała od nich, mogła wspierać potrzebujących $^{146}$. Pochwalając wybór życia w dziewictwie poświęconym Bogu, Hieronim z jednej strony wyraża uznanie dla Pauli, że dzięki swej troskliwości zachowała dziewicą swą córkę, z drugiej jednak strony dziwi się, że nie była zadowolona $\mathrm{z}$ wyboru tego właśnie stanu realizowania życia, jakiego dokonała córka i oburzała się, że nie chciała być żoną żołnierza ${ }^{147}$.

Słowa krytyki naszego Autora nie tylko nie ominęły tych, co z własnej winy nie chrzcili swych dzieci, ale także dotknęły na przykład matkę, która zaniedbywała swą córkę ofiarowaną przez nią Bogu ${ }^{148}$. Jak możemy przekonać się z innego jego listu, za nieszczęśliwych uważał również takich rodziców i chrześcijan, którzy nie mając doskonałej wiary „do dziewictwa posyłają niekształtne i ułomne córki, ponieważ nie znajdują odpowiednich zięciów”, choć przyznaje też, że można spotkać i takich, którzy uważając się za religijnych ,dają dziewicom niewielkie wyposażenie, wystarczające z trudem na ich utrzymanie, zaś cały majątek oddają dzieciom świeckim płci obojga”, co

\footnotetext{
${ }^{141}$ Hieronymus, Epistola 108, 26, PL 22, 902, ŹMT 61, 185.

${ }^{142}$ Hieronymus, Epistola 66, 3, PL 22, 640, ŹMT 55, 135.

${ }^{143}$ Hieronymus, Epistola 54, 6, PL 22, 552, ŹMT 55, 40.

${ }^{144}$ Por. Hieronymus, Epistola 130, 5, PL 22, 1110.

145 Tamże 130, 6, PL 22, 1110. ŹMT 63, 194-195.

146 Por. tamże 130, 7, PL 22, 1111, ŹMT 63, 196.

${ }^{147}$ Por. Hieronymus, Epistola 22, 20, PL 22, 407.

148 Por. Hieronymus, Epistola 107, 6, PL 22, 873.
} 
miał także uczynić pewien bogaty prezbiter, który „pozostawił bez środków do życia swe dwie córki, które chciały złożyć ślub dziewictwa, a cały majątek przekazał swym synom, by mogli żyć w największym zbytku"149. Z takim zachowaniem wobec własnych dzieci, można się, zdaniem naszego Autora, spotkać nierzadko także ze strony niektórych matek.

2. Formacja moralna. Wychowanie człowieka nie może się ograniczać tylko do formacji religijnej, ale musi uwzględniać także formację moralną, co potwierdza Klemens, a w szerszym jeszcze stopniu Hieronim.

Gdy chodzi o Klemensa, to czytając jego Kobierce możemy się przekonać, iż poruszając zagadnienie małżeństwa zauważa, że należy się żenić nie tylko ze względu na potrzeby ojczyzny, czy też po to, by pozostawić sukcesję własnym dzieciom, a także, by „doprowadzić świat do maksymalnej doskonałości”"150. Można więc przypuszczać, że autor tych słów stał na stanowisku, by równolegle z formacją religijną zabiegać także o moralno-ascetyczna, która ma przede wszystkim chronić człowieka przed zepsuciem i upadkiem moralnym ${ }^{151}$.

Potwierdzenie tego znajdujemy z kolei u Hieronima, którego szczegółowe pouczenia, adresowane zwłaszcza do dziewcząt mających kiedyś wstąpić do klasztoru, miały za cel to, by człowiek w dzieciństwie nie uczył się tego, czego później będzie się musiał oduczać, ponieważ „z trudem daje się wykorzenić to, czym nasiąkł młody umysł" ${ }^{\prime 52}$. Wypełniając niejako to założenie, w odróżnieniu od Klemensa, zawsze jednak w kontekście interesującego nas tematu, Hieronim podaje szereg wskazówek praktycznych, dotyczących tak relacji do świata w szerokim tego słowa znaczeniu, jak i do siebie samego.

Gdy chodzi o postawę, jaką młody człowiek winien zająć wobec świata, nasz Autor uważał, że córka winna być oddana na wychowanie do klasztoru po to, by „nie znała świata, żyła anielsko, by była w ciele bez ciała” ${ }^{153}$. Z tego też powodu wskazanym jest, aby nie wdawała się w rozmowy ze świeckimi, czy też przebywała ze złymi dziewczętami ${ }^{154}$.

Aby zaś nie utracić cnoty wstydliwości ${ }^{155}$, unikać winna także towarzystwa „pięknie uczesanych i uśmiechających się młodzieńców”156, swawoli wieku

\footnotetext{
${ }^{149}$ Hieronymus, Epistola 130, 6, PL 22, 1111, ŹMT 63, 195.

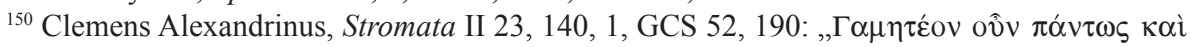

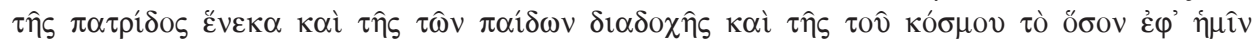

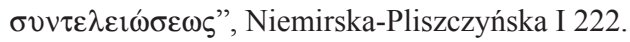

${ }^{151}$ Por. Stępniewska, Wychowanie rodzinne dziewczat, s. 173.

${ }^{152}$ Hieronymus, Epistola 107, 4, PL 22, 872: „ne discat in tenero, quod ei postea dediscendum est”, ŹMT 61, 152.

${ }^{153}$ Tamże 107, 13, PL 22, 877: „nesciat saeculum, vivat angelice, sit in carne sine carne”, ŹMT $61,156$.

${ }^{154}$ Por. tamże 107, 11, PL 22, 876.

${ }_{155}$ Por. tamże 107, 7, PL 22, 874.

${ }^{156}$ Tamże 107, 9, PL 22, 875, ŹMT 61, 155.
} 
chłopięcego ${ }^{157}$, koleżanek szlachetnie urodzonych i pięknie śpiewających, czy służących, które często nie potrafią dochować dyskrecji, ale szukać towarzystwa dziewczyny „poważnej, bladej, zaniedbanej i smutnej” 158 . Kandydatka do życia we wspólnocie zakonnej, nie powinna też w sposób nieumiarkowany spożywać wina, które prowadzi do rozpusty. Mówiąc to zaznacza jednak, że „przed dojściem do dojrzałości niebezpieczna jest dla młodych ludzi ciężka wstrzemięźliwość". Dlatego też do czasu uzyskania dojrzałości, powinna ona nieco używać wina ,ze względu na żołądek" ${ }^{159}$. Nie powinna też jadać publicznie, brać udziału w biesiadach rodziców ${ }^{160}$, godach małżeńskich, hucznych zabawach rodzinnych ${ }^{161}$, ale jedynie pokrzepiać się przez spożywanie mięsa ${ }^{162}$. Autor poleca również spożywanie jarzyn, mąki, rzadziej zaś ryb ${ }^{163}$.

Celem stosowania tak skromnych posiłków jest, według Hieronima, wypracowanie u dziecka nie tylko „,noty wstrzemię́liwości, polegającej na tym, że nie zna się przedmiotu swych zachcianek"164, opanowywanie pożądliwości $^{165}$, czy też ochrona przed przyzwyczajeniem do życia $\mathrm{w}$ zbytku ${ }^{166}$, ale ma też swój cel pozytywny, jakim jest uzupełnienie brakujących sił w człowie$\mathrm{ku}^{167}$. Dlatego też pokarm spożywać należy w takiej ilości, by dziecko zawsze odczuwało głód, ale jednak, by starczyło mu sił na później ${ }^{168}$. Zwraca też uwagę i przestrzega, by córka poświęcona Bogu w dozgonne dziewictwo, nie bawiła się złotem oraz purpura, ponieważ te rzeczy wyrządzają szkodę jej obyczajom ${ }^{169}$. Dlatego też w liście do Gaudencjusza zauważa, że niektóre matki, poświęciwszy córkę do dziewictwa, mają zwyczaj ubierać ją w ciemną tunikę, okrywać ciemnym płaszczem, pozbawiać głowę i szyję wszelkich ozdób, a czynią tak dlatego, aby córka nie uczyła się w młodości posiadania tego, czego później będzie musiała się pozbyćc ${ }^{170}$.

Niewątpliwie Hieronim, mając to wszystko na uwadze, wyrażał przekonanie, że córka nie może zapominać o tym, że jej strój winien wskazywać na

${ }^{157}$ Por. tamże 107, 4, PL 22, 871: „Procul sit aetas lasciva puerorum”.

${ }^{158}$ Tamże 107, 9, PL 22, 875, ŹMT 61, 155.

159 Tamże 107, 8, PL 22, 874: „Dicat iam nunc et vinum non bibere, «in quo est luxuria» (Eph $5,18)$. Ante annos robustae aetatis, periculosa est teneris, et gravis abstinentia. Usque ad id tempus, si necessitas postulaverit [...] et vino utatur modico propter stomachum”, ŹMT 61, 155.

${ }^{160}$ Por. tamże: „Non vescatur in publico, id est, in parentum convivio”, ŹMT 61, 155.

${ }^{161}$ Por. tamże.

162 Por. tamże.

${ }^{163}$ Por. tamże 107, 10, PL 22, 875-876.

${ }^{164}$ Tamże 107, 8, PL 22, 874: „tamen ego arbitror securioris continentiae esse, nescire quod quaeras", ŹMT 61, 154.

${ }^{165}$ Por. tamże: , ne videat cibos quos desideret”.

${ }^{166}$ Por. tamże: „non docens luxuriam”.

${ }^{167}$ Por. tamże.

${ }_{168}$ Por. tamże 107, 10, PL 22, 875-876, ŹMT 61, 156.

${ }_{169}$ Por. tamże 107, 4, PL 22, 872: ,in auro atque purpura ludere: [...] moribus officit”.

${ }^{170}$ Por. Hieronymus, Epistola 128, 2, PL 22, 1096: „ne habere discat in tenero, quod postea ponere compellatur". 
Chrystusa-Oblubieńca, któremu ona została przyobiecana. Dlatego matka nie powinna przekłuwać uszu córce, malować jej ust szminką i purpura, ozdabiać szyję perłami i złotem, obciążać głowy drogimi kamieniami czy przypalać włosów ${ }^{171}$, a obowiązkiem z kolei córki jest wzgardzić jedwabiem, złotymi ozdobami oraz klejnotami ${ }^{172}$. Z tego też powodu gani Pretekstatę, żonę Hymeriusza, stryja Eustochium, za zbytnie posłuszeństwo wobec męża, uważając, że przenosiła je nad Chrystusa i zamieniła dziewicy Eustochium „strój i wygląd, a zaniedbane włosy ozdobnie ułożyła" wbrew złożonemu przez tę dziewczynę ślubowi i na przekór życzeniu matki ${ }^{173}$.

Tenże Autor, nie tylko udzielał wskazań dla dziewcząt, mających poświęcić się Bogu, ale także umiał dostrzegać tę skromność u młodych kobiet, które wybrały drogę życia w małżeństwie. Takim przykładem dla niego była młoda, dwudziestoletnia Blezyla, która ubierała się ze skromnością, unikając nadętości i pychy, co odpowiadało jej ,wewnętrznemu usposobieniu”174, ukształtowanemu już w dzieciństwie.

Hieronim nie pominął także troski o higienę osobistą. Jego zdaniem, dziecko, w sytuacji potrzeby, powinno korzystać także z łaźni ${ }^{175}$. Uściśla to nieco dalej zaznaczając, że dziewczynka nie powinna się jednak kapać razem z eunuchami oraz niewiastami zamężnymi, ponieważ, pierwsi „nie pozbywają się usposobienia męskiego, drugie zaś przedstawiają odrażający widok z powodu nabrzmiałych brzuchów" ${ }^{176}$. Kierując te uwagi do adresatki listu Lety, wyraża jednak przekonanie, że nie podoba mu się ,mycie u dziewczyny dorosłej”, która „powinna wstydzić się siebie samej” i oglądania siebie nagiej ${ }^{177}$. Swoje zaś stanowisko uzasadnia tezą, iż tak jak czuwaniami i postami umartwia się ciało, wstrzemięźliwością gasi płomienie pożądliwości, zaniedbaniem zewnętrznego wyglądu oszpeca się naturalną piękność, to tym bardziej nie powinno się wzniecać uśpionych ogni przebywając w gorącej łaźni ${ }^{178}$. Według Hieronima, oddana na wychowanie do klasztoru dziewczyna znajdzie tam najlepszą okazję, by oduczyć się zwyczaju przysięgania ${ }^{179}$, jak również i kłamstwa, które powinno być uważane za świętokradztwo ${ }^{180}$.

${ }^{171}$ Por. Hieronymus, Epistola 107, 5, PL 22, 872-873.

${ }^{172}$ Por. tamże 107, 10, PL 22, 875-876; tamże 107, 12, PL 22, 876-877.

${ }^{173}$ Por. tamże 107, 5, PL 22, 872, ŹMT 61, 153.

${ }^{174}$ Hieronymus, Epistola 39, 1, PL 22, 466: „Humilitas vestium non (ut in plerisque solet) tumentes animos arguebat: sed cum interiori se mente dejecerat”.

${ }^{175}$ Por. Hieronymus, Epistola 107, 8, PL 22, 874.

176 Tamże 107, 11, PL 22, 876: ,ne virgo Christi cum eunuchis lavet, nec cum maritatis feminis: quia alii non deponunt. animos virorum, aliae tumentibus uteris, praeferunt foeditatem", ŹMT 61, 157.

${ }^{177}$ Por. tamże 107, 11, PL 22, 876: „Mihi omnino in adulta virgine lavacra displicent, quae seipsam debet erubescere, et nudam videre non posse", ŹMT 61, 157.

${ }^{178}$ Por. tamże 107, 11, PL 22, 876: „cur e contrario balnearum fomentis sopitos ignes suscitat?”

${ }^{179}$ Por. tamże 107, 13, PL 22, 877.

${ }^{180}$ Por. tamże 107, 13, PL 22, 877: „mentiri sacrilegium putet”. 
Klemens Aleksandryjski, chociaż w swych Kobiercach nie zajmuje się tym tematem, to nie pomija jednak konieczności troski o zdrowie fizyczne dziecka, które w dużej mierze zależy od zdrowia rodziców. Na potwierdzenie tego przytacza opinię polityka ateńskiego Krytiasza (ok. 460-403), ucznia Sokratesa, który zastanawiał się, co powoduje, że dzieci stają się sprawne fizycznie. Odpowiadając na to pytanie doszedł do wniosku, że powodem tego jest to, iż nie tylko ojciec uprawia ćwiczenia gimnastyczne, intensywnie się odżywia i hartuje swe ciało, ale także matka mającego się narodzić dziecka ma silne ciało i również korzysta $\mathrm{z}$ ćwiczeń gimnastycznych ${ }^{181}$.

To wychowanie moralno-ascetyczne nie ogranicza się jednak tylko, jak zauważamy w listach Hieronima, do zakazów czy nakazów. Strydończykowi chodziło nie tylko o wypracowanie takich cnót, jak skromność, czy wstrzemięźliwość, ale również o położenie nacisku na to, by młody człowiek nauczył się kochać: tego przede wszystkim powinna dziecka nauczyć matka. Potwierdzenie tego znajdujemy w jednym z listów, z którego wyraźnie wynika, że nie ma nikogo sprawiedliwszego nad matkę, która między dzieci rozdzieliła mienie, wzgardziła bogactwami, ucząc je w ten sposób, co powinno się kochać ${ }^{182}$. Ta myśl Hieronima obecna jest także, w naszym przekonaniu, w wypowiedzi Klemensa, który w kontekście stwierdzenia, że małżeństwo jest pomocą dla człowieka w podeszłym wieku ${ }^{183}$, wypowiada przekonanie, iż małżonka wychowuje dzieci, aby one z kolei nauczyły się pielęgnować starych rodziców ${ }^{184}$.

3. Formacja intelektualna. Proces wychowawczy, aby był kompletny i wszechstronny, nie może także pomijać formacji intelektualnej, która winna obejmować zarówno dziewczęta, jak i chłopców. Ten rodzaj formacji powinien rozwijać się w wielu aspektach. Nigdy jednak nie może być tak, jak zaznacza Hieronim, aby dziecko poddane tej formacji znienawidziło na zawsze naukę, przed czym m.in. przestrzegał Letę ${ }^{185}$. $Z$ tego też względu należy mieć na uwadze wiek dziecka. Trudno jest bowiem, jak to stwierdza w liście do Gaudencjusza, ,pisać do małej dziewczynki, która nie rozumie, co mówisz”"186.

Jedną z form formacji intelektualnej jest kształcenie dziecka. Tak m.in. postapiła matka mnicha Rustyka, która wysłała swego syna na studia do Ga-

${ }^{181}$ Por. Clemens Alexandrinus, Stromata VI 2, 9, 2-3, GCS 52, 428; Critias, Frgm. 1, ed. F.C. Mueller, FHG II 68, lub frgm. 32, ed. Diels, II 391, 3-7.

${ }^{182}$ Por. Hieronymus, Epistola 66, 3, PL 22, 640: „Quid matre iustius, quae inter liberos opibus distributis, docuit divitias contemnendo, quid filii amare deberent?”, XMT 55, 135.

${ }^{183}$ Por. Clemens Alexandrinus, Stromata II 23, 141, 1.

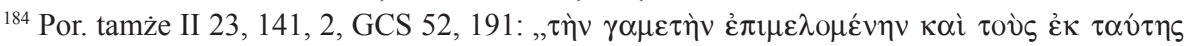

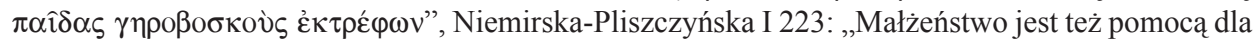
człowieka podeszłego wiekiem. Stawia obok niego małżonkę, która świadczy mu opiekę i wychowuje dzieci z niej zrodzone, by one z kolei pielęgnowały starych rodziców”.

${ }^{185}$ Por. Hieronymus, Epistola 107, 4, PL 22, 871: „Cavendum in primis, ne oderit studia, ne amaritudo eorum praecepta in infantia, ultra rudes annos transeat”.

${ }^{186}$ Por. Hieronymus, Epistola 128, 1, PL 22, 1096. 
lii, nie szczędząc na to wydatków ${ }^{187}$. W skład formacji intelektualnej wchodzi także troska rodziców o posługiwanie się przez ich dziecko pięknym językiem. Dostrzegał to również Hieronim, kiedy przypominał rodzicom o tym obowiązku, mając jednocześnie na uwadze fakt, iż w dużej mierze zależy to od stopnia wykształcenia i poziomu wychowawcy ${ }^{188}$. O pięknie języka, jak czytamy w jego listach, świadczy wytworność wysławiania się. Przykładem opanowania tej umiejętności była dla niego wspomniana już Blezyla, u której pochwala także wierność pamięci i bystrość umysłu ${ }^{189}$, oraz wysłany na studia do Galii Rustyk, wobec którego matka żywiła nadzieję, że u niego ,żyzność i wytworność mowy galickiej zaprawi się rzymską powagą"190. Czyniąc zaś aluzję do wskazań wielkich mówców i teoretyków wymowy, Hieronim był zdania, że należy troszczyć się nie tyle o wielość wypowiadanych słów, co o bogactwo przekazywanych myśli ${ }^{191}$. Z tego też względu z uznaniem pisał o matce Grakchów, Kornelii (II prz. Chr.), a także o ojcu mówcy rzymskiego Hortensjusza, którzy pod tym względem mieli wobec swych synów wielkie zasługi ${ }^{192}$. Stąd też w trosce o piękno języka ojczystego (łaciny), Hieronim podkreślając znaczenie uczenia się go uważał, że zaniedbanie go sprawia, iż „ta [łacina] nie uczona od młodości, nie urabia młodych ust, wymowa przybiera obce brzmienie, zaś język ojczysty szpeci się obcymi naleciałościami"193. Dlatego też nie może dziwić, że nasz Autor kładł nacisk na to, by dziecko, a ma tu na myśli zwłaszcza dziewczynkę, nie uczyło się brzydkich słów, mówienia półsłowami, które szkodzi mowie ${ }^{194}$, ani też świeckich pieśni, w miejsce których powinna uczyć się psalmów ${ }^{195}$; nie powinna również słuchać gry na instrumentach muzycznych ani ich poznawać ${ }^{196}$.

Nasz Autor przywiązywał wagę nie tylko do opanowania języka ojczystego, ale także, dla pełniejszej formacji intelektualnej, do znajomości języków obcych. Stąd też podziwiał tę umiejętność u Blezyli, która znała płynnie język grecki i mówiła czystą, bez greckiej naleciałości, łaciną, i z łatwością opanowała też język hebrajski ${ }^{197}$.

${ }^{187}$ Por. Hieronymus, Epistola 125, 6, PL 22, 1075.

${ }^{188}$ Por. Hieronymus, Epistola 107, 4, PL 22, 872.

${ }^{189}$ Por. Hieronymus, Epistola 39, 1, PL 22, 465: ,nitorem linguae, memoriae tenacitatem, acumen ingenii?"; zob. K. Thraede, Frau, RACh VIII 222.

${ }^{190}$ Hieronymus, Epistola 125, 6, PL 22, 1075, ŹMT 63, 155.

${ }^{191}$ Por. tamże; zob. Cicero, De oratore III 36; Quintilianus, Institutio oratoria II 8, 11.

192 Por. Hieronymus, Epistola 107, 4, PL 22, 872.

${ }^{193}$ Hieronymus, Epistola 107, 9, PL 22, 875: „Sequatur statim Latina eruditio: quae si non ab initio os tenerum composuerit, in peregrinum sonum lingua corrumpitur, et externis vitiis sermo patrius sordidatur", ŹMT 61, 155; por. Quintilianus, Institutio oratatoria I 1, 13.

${ }^{194}$ Por. Hieronymus, Epistola 107, 4, PL 22, 872.

${ }^{195}$ Por. tamże 107, 4, PL 22, 871.

${ }^{196}$ Por. tamże 107, 8, PL 22, 874.

${ }^{197}$ Por. Hieronymus, Epistola 39, 1, PL 22, 465-466. 
Prócz znajomości języka ojczystego i języków obcych nasz Strydończyk kierując się wskazaniami Kwintyliana ${ }^{198}$, doradza adresatce listu, w jaki sposób ma ona swą córkę uczyć pisania: zachęca matkę, aby na początku wykonała swej córce litery z bukszpanu lub kości słoniowej i zapoznała ją z ich nazwami. Córka winna się nimi bawić, ale tak, by zabawa stała się nauką. Winna ona także zapamiętać kolejność liter (= alfabet), oraz umieć na pamięć ich nazwy, jak piosenkę. Ucząc dziecko w ten sposób, winno się także pamiętać o zmienianiu porządku liter tak, by środkowe łączyć z ostatnimi, a pierwsze ze środkowymi, by litery poznawało nie tylko z brzmienia, ale i z wyglądu. Gdy córka, jak czytamy dalej, zacznie już pisać rylcem po tabliczce woskowej, cudza ręka winna kierować jej delikatnymi paluszkami. Można też wyryć litery na tablicy, by dziecko mogło rylcem pociągać po śladach liter, bez wysuwania go na zewnątrz ${ }^{199}$. Dziecko powinno także posiąść umiejętność łączenia zgłosek $^{200}$, uczyć się wyrazów oraz umiejętnie wiązać słowa ${ }^{201}$. Również imiona służące do składania słów, nie powinny być przypadkowe, ale dobrane i świadomie ściśle określone; winny to być, w miejsce imion pogańskich bohaterów, imiona proroków i apostołów oraz z katalogu patriarchów, który poznawany W ten sposób, zostanie utrwalony w pamięci ${ }^{202}$. W swych wskazaniach odnoszących się do formacji intelektualnej, Hieronim radził także, aby dziewczynka poznawała rytm greckich wierszy ${ }^{203}$, oraz wiele czytała ${ }^{204}$, pamiętając jednak o tym, że nie wszystko, co poznaje, można naśladować w życiu ${ }^{205}$.

Obok formacji intelektualnej nasz Autor nie pomijał także umiejętności zdobywanych podczas prac ręcznych. W przypadku dziewczynki uważał, że winna ona uczyć się „prząść wełnę, trzymać kądziel, kłaść na kolanach koszyk, obracać wrzeciono, rozprowadzać palcem nici”. Podczas tych prac winna ona posiąść umiejętność szycia odzieży, która chroni przed zimnem, ale nie takiej, która obnaża odziane ciało ${ }^{206}$.

\section{WNIOSKI}

Analiza nauczania Klemensa i Hieronima, w pismach będących przedmiotem naszego studium, prowadzi nas do następujących wniosków:

\footnotetext{
${ }^{198}$ Por. Qintilianus, Institutio oratoria I 2, 28.

${ }_{199}$ Por. Hieronymus, Epistola 107, 4, PL 22, 871; Epistola 128, 1, PL 22, 1096; zob. Quintilianus, Institutio oratoria I 2, 27.

${ }^{200}$ Por. Hieronymus, Epistola 107, 4, PL 22, 871: „Syllabas iungat”.

${ }^{201}$ Por. Hieronymus, Epistola 128, 1, PL 22, 1096: „discat nomina, verba consociet”.

${ }^{202}$ Por. Hieronymus, Epistola 107, 4, PL 22, 871.

${ }^{203}$ Por. tamże 107, 9, PL 22, 875.

${ }^{204}$ Por. tamże 107, 10, PL 22, 875.

${ }^{205}$ Por. tamże 107, 12, PL 22, 877.

${ }^{206}$ Por. tamże 107, 10, PL 22, 875: „Discat et lanam facere, tenere colum, ponere in gremio calathum, rotare fusum, stamina pollice ducere [...]. Talia vestimenta paret, quibus pellatur frigus, non quibus vestita corpora nudentur", ŹMT 61, 156.
} 
1. Celem wychowania jest ochrona dziecka przed złem oraz wypracowanie w nim umiejętności przezwyciężania zła dobrem (Hieronim). Wychowanie nie jest czymś obojętnym dla dobra moralnego (Klemens) ale, jak podkreślaja to obaj autorzy, jest ono obowiazkiem. Proces wychowawczy wymaga dla siebie wytworzenia właściwego klimatu, który zapewnia odpowiedni rozwój tak od strony psychicznej, jak i osobowościowej w obrębie własnego środowiska. Ten proces winien być przeprowadzany w duchu odpowiedzialności, a każde z dzieci winno być traktowane równo. Obaj Autorzy dopuszczają stosowanie wobec dziecka nagany, ale winna ona być udzielana z umiarem, w duchu miłości i bez przesady. W przeciwieństwie do Klemensa, który na ten temat się nie wypowiada, Hieronim proponuje wobec dziewczynki bardziej łagodne postępowanie wyrażające się w pochwałach i dawanych podarkach, których celem jest pobudzanie zdolności, radość z sukcesów, a smutek z powodu niepowodzeń. Lektura obu pism pozwoliła zauważyć, iż tylko Hieronim, i to w sposób pośredni, wypowiada się na temat pozytywnych skutków rywalizacji w nauce.

2. Pierwszymi wychowawcami dziecka są przede wszystkim rodzice, którzy muszą pod tym względem spełniać określone wymagania. Według Hieronima i Klemensa żona i matka powinna być osobą pobożną o głębokiej wierze wyrażającej się w podejmowanych umartwieniach, udzielanej jałmużnie ubogim, poszanowaniu osób duchownych, pokorze w sercu i odzieniu oraz umiarkowaniu w mowie (Hieronim). Matka dla swej córki winna być nauczycielka, którą ona ma naśladować. Konieczna jest także jej stała obecność przy dziecku w miejscach publicznych, także i w kościele. Matka nie powinna też zostawiać córki samej w domu (Hieronim). Hieronim, choć najwięcej w swych listach poświęcił uwagi temat wychowania córki przez matkę, to jednak nie pominął faktu, że matka może także wychowywać własnego syna, którą to możliwość dostrzegał również Klemens. W procesie wychowawczym ważną rolę odgrywa także ojciec (Hieronim; Klemens), który posiada w tym względzie pierwszorzędną rolę zwłaszcza wobec syna (Klemens).Dla Klemensa ojcem jest ten, którzy kształci co oznacza, że jest pierwszą przyczyną sprawczą procesu nauczania. Według Aleksandryjczyka wychowywanie potomstwa oraz jego kształcenie nie może być w sprzeczności z Bogiem i wolą Logosu, z przykazaniami Bożymi i nadzieją. Obaj Autorzy szczególny nacisk kładli na to, aby rodzice i stanowili przykład dla dziecka tak, aby ich postępowanie nie prowadziło go do grzechu. Odpowiedzialność za dorosłe i samodzielne dzieci spada na rodziców, szczególnie zaś za niedorosłe (Hieronim). Zwiększa się ona zwłaszcza wtedy gdy rodzice, na mocy ślubu, postanowili oddać córkę na służbę Bogu. Na podstawie lektury analizowanych pism obu Autorów możemy się przekonać, że Hieronim, w odróżnieniu od Klemensa poszerza zakres odpowiedzialności za wychowanie, ponieważ włącza w jego proces obok matki i ojca, także krewnych: babkę, dziadka i ciotkę, wobec których stawia określone wymagania religijne i moralne. W wychowywaniu dziecka, a szczególnie dziewczynki pomagała także piastunka (Hieronim), wobec której Autor 
stawiał także wysokie wymagania religijne i moralne. Taka opiekunka przez przykład własnego swego życia przyczyni się do rozbudzenia u dziecka wiary i ukształtuje w cnocie. Wychowawczyni spełniająca te kryteria winna też umieć prowadzić z dzieckiem zajęcia praktyczne (Hieronim). Hieronim nie pomija faktu, iż ważną rolę wychowawczą spełnia także nauczyciel, który winien być osobą godną pod względem wieku, życia i wykształcenia. Obaj Autorzy pochwalają tych co w sposób odpowiedzialny podjęli się trudu kierowania procesem wychowawczym dziecka. Zwłaszcza przez Hieronima wszelkie przejawy zaniedbania matki wobec dziecka nie tylko zostały poddane krytyce. Dla niego świętokradztwem był brak troski o rozwój duchowy dziecka poświęconego Bogu, zaś zbrodnią fakt nie ochrzczenia dziecka. Autor ten uważa również, że w przypadku gdy matka ma świadomość, że trudno jej sprostać zadaniu wychowania córki, to w takiej sytuacji winna ją oddać do klasztoru.

3. Kolejnym zagadnieniem, które zostało przybliżone w tym opracowaniu był człowiek rozumiany jako podmiot procesu wychowawczego. Lektura przede wszystkim Kobierców Klemensa pokazała, że nie zawsze pozytywnie zapatrywano się na wydawanie na świat potomstwa. Klemens nie tylko odrzucił te poglądy, ale ocenił je jako grzeszne a nawet bluźniercze. W jego przekonaniu powołanie do życia potomstwa powinno dokonywać się w sposób odpowiedzialny i z roztropnością. Nie należy więc popadać w skrajność unikania małżeństwa pod pozorem trudności małżeńskich, lub też nieumiarkowanego i grzesznego pożycia seksualnego. Przede wszystkim dla Aleksandryjczyka bezdzietność jest brakiem i bólem małżonków, obaj natomiast podkreślają, że dziecko jest darem Bożym i jako takie winno być poddane procesowi wychowawczemu.

4. W ostatnim punkcie naszego opracowania poruszyliśmy kwestię dotycząca przedmiotu wychowania młodego człowieka. W pierwszej kolejności przedstawione zostały poglądy obu Autorów na temat formacji religijnej, której początkiem jest przyjęty przez niego chrzest (Hieronim). Celem tego procesu wychowawczego jest pogłębienie duchowe człowieka, nauczenie go bojaźni Bożej, napełnieniem go mądrością, takim ukształtowaniem duszy by stała się ona świątynią Pana (Hieronim). Tę prawdę uwypuklił także Klemens gdy wskazywał na świętość jako cel tej formacji. Do poprawnej formacji religijnej przyczynia się także troska o czystość wiary (Klemens). Tę prawdę bardziej jednak rozwinął Hieronim podając sposoby jej pogłębiania poprzez lekturę wybranych pism ortodoksyjnych autorów okresu wczesnochrześcijańskiego, studium Pisma św., obecność w kościele oraz stosowanie praktyk ascetycznych. Tak ukształtowana wiara ma usposobić dziecko do mężnego jej wyznawania. Tenże Autor wielką wagę przypisywał także takiemu wychowaniu, które sprzyja wyborowi dziewictwa poświęconemu Bogu. Ze słowami natomiast krytyki spotkały się takie czyny jak: nie ochrzczenie dziecka czy zaniedbywanie córki ofiarowanej Bogu. Hieronimowi nie podobało się również to, że kieruje się do klasztoru osoby ułomne lub materialnie dyskryminuje 
te, które wybrały życie w dziewictwie. Analiza pism obu Autorów pokazuje, że ucząc na temat wychowania potomstwa Uwzględniają oni w tym procesie także formację moralną. W porównaniu jednak z Klemensem, Hieronim temu zagadnieniu poświęca więcej miejsca. Ta formacja moralna ma doprowadzić świat do doskonałości (Klemens) i uchronić człowieka przed zepsuciem i upadkiem moralnym. Celem ogólnym przestróg, jakie wypowiada z kolei Hieronim pod adresem dziewcząt mających kiedyś wstąpić do klasztoru, jest nauczenie człowieka tego czego później nie będzie się musiał oduczać. Autor ten, w odróżnieniu od Klemensa podaje szereg wskazówek praktycznych dotyczących tak relacji człowieka do świata, jak i do siebie samego. Według niego należy unikać świata i złego towarzystwa, nie wdawać się w rozmowy ze świeckimi, przebywania ze złymi dziewczętami. By nie utracić cnoty wstydliwości stronić należy też od młodzieńców, swawoli, koleżanek szlachetnie urodzonych i pięknie śpiewających oraz służebnic, ale szukać towarzystwa bardzo skromnej dziewczyny. Kandydatka do życia we wspólnocie zakonnej nie powinna w sposób nieumiarkowany spożywać wina, unikać powinna także publicznego spożywania posiłków, udziału w biesiadach rodziców, godach małżeńskich, hucznych zabawach rodzinnych. Nie może też patrzeć na pokarmy lecz spożywać skromne posiłki. Celem takiego postępowania jest wypracowanie u dziecka cnoty wstrzemięźliwości, ochrona przed pożądliwością oraz zbytkiem. Nie należy też przywiązywać wagi do wyszukanego stroju, noszenia kolczyków, malowania się, ozdabiania perłami i złotem, drogimi kamieniami czy przypalania włosów ale należy tym wszystkim wzgardzić. Uwagi i wskazania Hieronima nie pominęły także troski o higienę osobistą dziewczynki z zastrzeżeniem, że w łaźni nie powinna ona ze względów moralnych i estetycznych myć się z eunuchami i kobietami zamężnymi. Na temat troski o zdrowie fizyczne rodziców i dziecka pisał także Klemens. Według Hieronima oddana na wychowanie do klasztoru córka, uniknie tam uczenia się przysięgania jak również kłamstwa. To wychowanie moralno - ascetyczne uwzględnia również zdobywanie cnoty miłości, której powinna dziecka nauczyć matka (Hieronim), wyrazem której jest opieka dzieci nad starymi rodzicami (Klemens). Do pełni realizacji procesu wychowawczego należy także formacja intelektualna, na temat której, w porównaniu z Klemensem wypowiadał się w swych listach tylko Hieronim. Ten rodzaj formacji powinien rozwijać się w wielu aspektach. Nie powinien on zniechęcać dziecka i być dostosowany do jego wieku. Na tę formację składają się odbyte studia, obejmuje ona także troskę o piękno języka, znajomość języka ojczystego i języków obcych, nauka pisania oraz roztropna znajomość literatury. Nasz Autor przestrzegał, zwłaszcza dziewczynki, by unikały brzydkich słów, mówienia półsłowami, nie uczyły się pieśni świeckich, nie powinny też poznawać i słuchać gry na instrumentach muzycznych. Obok formacji intelektualnej nasz Autor nie pomijał także umiejętności manualnych zdobywanych podczas prac ręcznych. Gdy chodzi o dziewczynkę, to powinna ona nauczyć się prząść wełnę oraz szyć. 
EDUCATION OF THE OFFSPRING ON AN EXAMPLE OF STROMATA OF CLEMENT OF ALEXANDRIA AND LETTERS OF ST. JEROME

(Summary)

The introduced article is composed of four parts. The first concerns the general principles relating to the education of man. The second part says about persons responsible for upbringing of the child, especially about the role of parents. In the third section, the reflections of both authors about the man, who is understood as the subject of the educational process, are presented. The last part approximates Jerome and Clement's teaching on the subject of the formation, which involves the religious, moral and intellectual formation.

translated Adam Ziółkowski SDS 